\title{
Oncogenic Mechanisms and Therapeutic Targeting of Metabolism in Leukemia and Lymphoma
}

\author{
Maximilian Stahl, ${ }^{1}$ Zachary D. Epstein-Peterson, ${ }^{1}$ and Andrew M. Intlekofer \\ Department of Medicine and Human Oncology \& Pathogenesis Program, Memorial Sloan Kettering Cancer \\ Center, New York, New York 10065, USA \\ Correspondence: intlekoa@mskcc.org
}

Leukemias and lymphomas acquire the capacity for unrestrained cell growth and proliferation in conjunction with loss of responsiveness to molecular programs that promote terminal differentiation. Malignant cells generate the building blocks required for rapid cell division through both increased acquisition of nutrients from the environment and reprogrammed intermediary metabolism to shunt these molecules into producing the protein, lipids, and nucleic acids that comprise cell biomass. These accelerated metabolic processes require energy in the form of ATP and reducing equivalents in the form of NADPH, which power biosynthetic reactions and buffer oxidative stress encountered by the metabolically active cancer cell. Cancer-associated metabolic alterations can also promote accumulation or depletion of specific metabolites that directly regulate cell fate and function, thereby coupling metabolic reprogramming to dedifferentiation and stemness. This review will focus on the mechanisms by which leukemia and lymphoma cells rewire cellular metabolism to support: (1) bioenergetics, (2) biomass accumulation, (3) redox balance, and (4) differentiation blockade. We will further highlight examples of how specific pathways of leukemia and lymphoma metabolism confer therapeutic vulnerabilities that can be targeted to inhibit growth or promote differentiation.

\begin{abstract}
$A^{t}$ a fundamental level, cancer is a problem of Ahijacked cellular metabolism (Vander Heiden et al. 2009). Normally, metazoan cells require "permission" from growth factors, cytokines, hormones, or antigen/costimulatory receptors to increase nutrient uptake. All cancers, including leukemias and lymphomas, acquire the capacity for cell-autonomous uptake of nutrients that circumvents normal regulatory
\end{abstract}

mechanisms (Palm and Thompson 2017). Such unrestricted nutrient uptake is critical to build the cellular biomass (protein, lipids, nucleic acids) necessary for rapid cell doubling (Fig. 1). Because the availability of specific nutrients in the environment does not precisely match the necessary outputs, cancer cells must rewire metabolic circuits to rapidly convert available nutrients into precursor metabolites

\footnotetext{
${ }^{1}$ These authors contributed equally to this work.

Editors: Michael G. Kharas, Ross L. Levine, and Ari M. Melnick

Additional Perspectives on Leukemia and Lymphoma: Molecular and Therapeutic Insights available at www.perspectivesinmedicine.org

Copyright $\odot 2021$ Cold Spring Harbor Laboratory Press; all rights reserved; doi: 10.1101/cshperspect.a035477 Cite this article as Cold Spring Harb Perspect Med 2021;11:a035477
} 
M. Stahl et al.

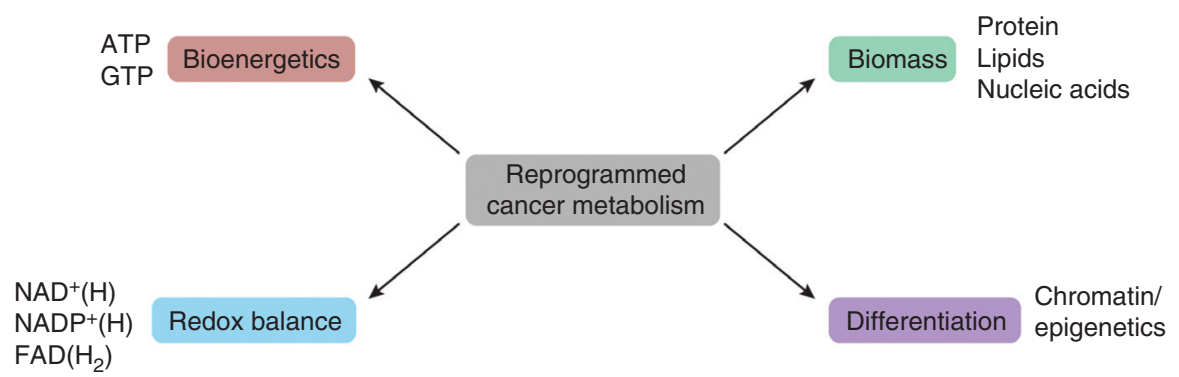

Figure 1. Key functions of reprogrammed cancer metabolism. Leukemias and lymphomas reprogram cellular metabolism to meet the anabolic demands of malignant growth and proliferation. Glycolysis and mitochondrial oxidative phosphorylation provide energy in the form of ATP and GTP (Bioenergetics). Metabolic intermediates are shunted into biosynthetic pathways that produce the protein, lipids, and nucleic acids required for cell doubling and division (Biomass). Malignant cells require increased regeneration of $\mathrm{NAD}^{+}$to enable oxidative biosynthetic reactions (e.g., nucleotides), as well as increased production of NADPH to fuel reductive biosynthetic reactions (e.g., lipids) and buffer oxidative stress (redox balance). Deregulation of specific metabolites or metabolic pathways can also disrupt chromatin marks, resulting in impaired differentiation and/or enhanced self-renewal (differentiation). (ATP) Adenosine triphosphate, (GTP) guanosine triphosphate, (NAD) nicotinamide adenine dinucleotide, (NADP) nicotinamide adenine dinucleotide phosphate, (FAD) flavin adenine dinucleotide.

that can be used to synthesize the macromolecules that comprise cell biomass. This intensive metabolic activity requires energy in the form of adenosine triphosphate (ATP) and reducing equivalents in the form of nicotinamide adenine dinucleotide phosphate (NADPH) to fuel biosynthetic reactions (Fig. 1).

As first described by Otto Warburg almost 100 years ago, most cancer cells rapidly ferment glucose to lactate regardless of oxygen availability (Warburg 1924, 1956). A high rate of glycolysis by cancer cells serves at least two important functions, which are often difficult to dissociate mechanistically: (1) ATP production and (2) generation of precursor molecules and reducing equivalents required for biosynthesis of macromolecules (Fig. 2; Vander Heiden et al. 2009). Surprisingly, the limited amount of ATP (maximum of 2 ATP per glucose) generated by glycolysis can be sufficient to support cell proliferation in highly glycolytic cancer cells without a requirement for additional ATP generated by mitochondrial oxidative phosphorylation (OXPHOS) (Birsoy et al. 2015; Sullivan et al. 2015). Running glycolysis at a high rate appears to necessitate the Warburg effect, which drives conversion of pyruvate to lactate by lactate dehydrogenase $(\mathrm{LDH})$ in order to rapidly regener- ate the cytosolic $\mathrm{NAD}^{+}$required to maintain glycolytic flux. However, despite the ability of glycolysis to provide adequate ATP, mitochondrial electron transport remains essential for virtually all cancer cells in order to regenerate the electron acceptors $\left(\mathrm{NAD}^{+}\right)$required for macromolecular biosynthesis (Hosios and Vander Heiden 2018). Moreover, certain cancer cells without high glycolytic flux, including leukemic stem cells and a subset of diffuse large B-cell lymphoma (DLBCL), appear to be particularly dependent on OXPHOS, which may be related to their preferential oxidation of alternative fuels that can only generate ATP through the mitochondria (Caro et al. 2012; Ye et al. 2016; Jones et al. 2018).

Proliferating cells must double their biomass in order to divide, which requires assembling all of the proteins, lipids, and nucleic acids that comprise the cell (Fig. 1; Hosios et al. 2016). A subset of carbohydrates, amino acids, lipids, and nucleotides can be acquired from the microenvironment for direct incorporation into macromolecules, However, a major function of cancer metabolism involves conversion of available nutrients, such as glucose and glutamine, into metabolic intermediates that can be directed into macromolecular biosynthetic pathways (Fig. 2; 


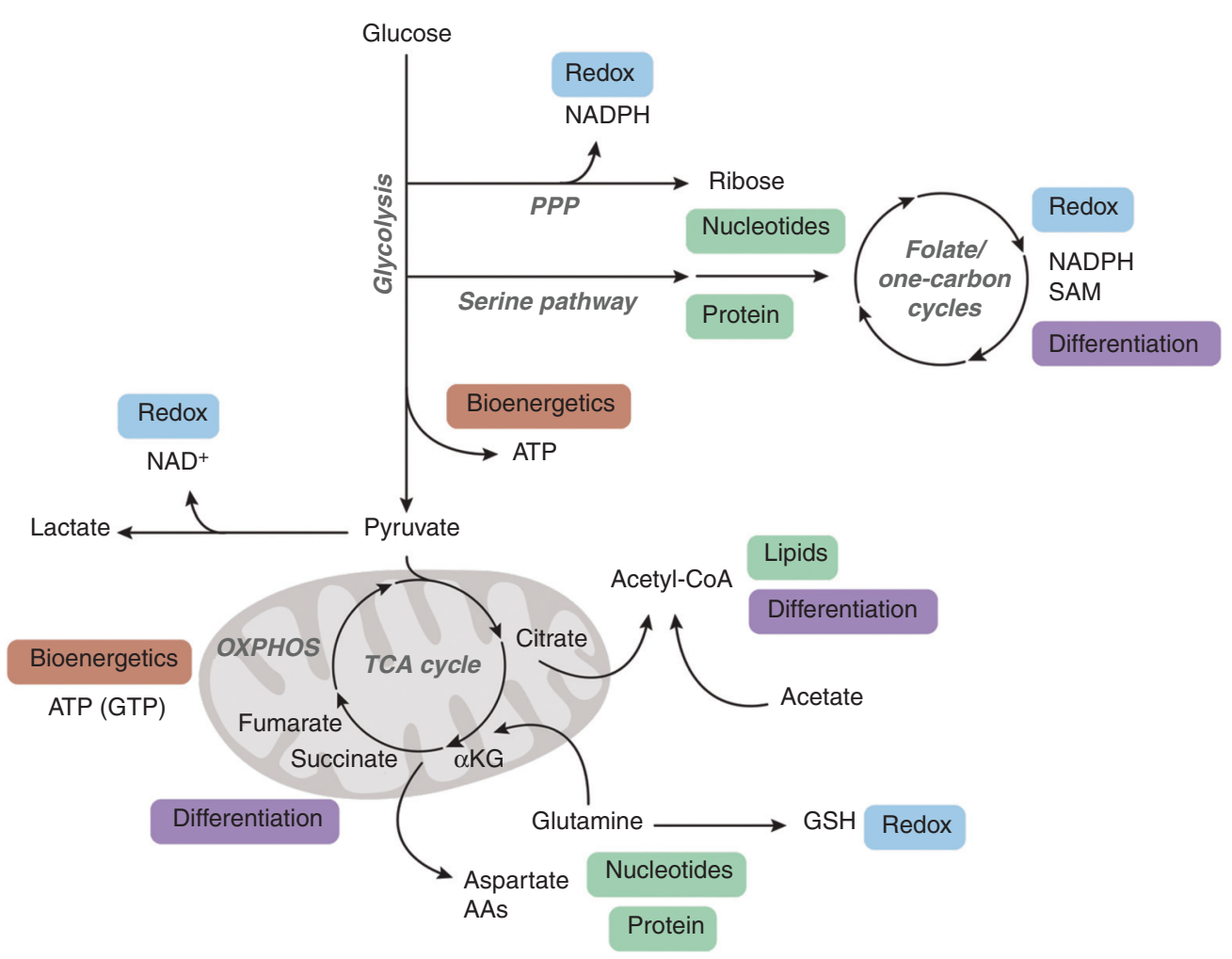

Figure 2. Simplified overview of metabolic pathways in leukemia and lymphoma. Altered and/or enhanced glycolysis, pentose phosphate pathway (PPP), serine biosynthetic pathway, folate/one-carbon cycles, tricarboxylic acid (TCA) cycle, oxidative phosphorylation (OXPHOS), lipid synthesis, and amino acid (AA) metabolism support bioenergetics (red), biomass accumulation (green), redox balance (blue), and differentiation blockade (purple). Most precursors, products, cofactors, and enzymes are intentionally absent for simplicity. (ATP) Adenosine triphosphate, (GTP) guanosine triphosphate, (NAD) nicotinamide adenine dinucleotide, (NADPH) nicotinamide adenine dinucleotide phosphate, (SAM) $S$-adenosyl methionine, ( $\alpha K G)$ alpha-ketoglutarate, $(\mathrm{GSH})$ reduced glutathione.

Vander Heiden and DeBerardinis 2017). Glycolytic intermediates provide a key pool of substrates for biosynthetic reactions: The pentose phosphate shunt produces ribose sugars for nucleotide biosynthesis; dihydroxyacetone phosphate can be converted into glycerol for lipid biosynthesis; serine biosynthesis from 3-phosphoglycerate operates in conjunction with the folate pathway to form one-carbon units for nucleotide production; and multiple glycolytic intermediates can be used for the synthesis of nonessential amino acids. Moreover, glucoseor-acetate-derived acetyl-CoA functions as a key building block for fatty acid and cholesterol biosynthesis.
Analogous to enhanced glucose consumption and glycolytic flux, most leukemias and lymphomas exhibit increased uptake and consumption of glutamine, or glutaminolysis (Fig. 2; Wise and Thompson 2010). Glutamine serves as a nitrogen donor for nucleotide synthesis and for transamination reactions to generate nonessential amino acids. Likewise, glutamine-derived aspartate functions as a key building block for nucleotide biosynthesis (Wise and Thompson 2010). Glutamine also serves as a carbon backbone to generate nonessential amino acids and glutathione, an exchange factor for the import of essential amino acids from the environment, a key anaplerotic 
M. Stahl et al.

substrate to maintain pools of tricarboxylic acid (TCA) cycle intermediates, and an alternative source of acetyl-CoA for lipid biosynthesis via reductive carboxylation. In addition, glutamine and glucose together supply hexosamine biosynthesis for $\mathrm{N}$ - and $\mathrm{O}$-linked glycosylation reactions.

Many of the common oncogenic pathways in leukemia and lymphoma (and other cancers) coordinate proliferation with reprogramming of cellular metabolism to meet the anabolic demands of growth and cell division. MYC oncoproteins are frequently overexpressed in leukemias and lymphomas through variety of mechanisms, including enhancer hijacking (Bahr et al. 2018; Schuijers et al. 2018), NOTCH1 activation (Sanchez-Martin and Ferrando 2017), or chromosomal translocations (Altman and Dang 2012). MYC exerts pleiotropic metabolic effects by promoting glucose uptake, glycolytic flux, glutamine uptake, glutaminolysis, nucleotide biosynthesis, lipid synthesis, and mitochondrial and ribosomal biogenesis (Stine et al. 2015). Likewise, RAS pathway activation enhances glucose uptake, increases flux through glycolysis and the nonoxidative pentose phosphate pathway, and promotes macropinocytosis of proteins/lipids that can be metabolized in lysosomes (Kimmelman 2015). Many genetic alterations in leukemias and lymphomas lead to constitutive PI3K/AKT/TOR pathway activation, enhancing glucose uptake, glycolytic flux, amino acid uptake, acetyl-CoA production, and synthesis of lipids and nucleotides (Saxton and Sabatini 2017). Additional leukemia- and lymphomaspecific genetic alterations that reprogram metabolism will be discussed throughout the review where relevant.

Redox balance refers to the relative availability of electron donors $\left(\mathrm{NADH}, \mathrm{FADH}_{2}\right.$, $\mathrm{NADPH})$ and electron acceptors $\left(\mathrm{NAD}^{+}, \mathrm{FAD}\right.$, $\mathrm{NADP}^{+}$) to perform reduction and oxidation reactions, respectively (Fig. 1). In simplistic terms, cancer cells must maintain sufficient supplies of NADPH and $\mathrm{NAD}^{+}$to meet the redox demands of anabolic proliferative metabolism (Hosios and Vander Heiden 2018). NADPH serves a crucial role in regenerating reduced glutathione and other antioxidants that can buffer oxidative damage from reactive oxygen species (ROS) (Sullivan and Chandel 2014). In addition, NADPH functions as an electron donor for key biosynthetic reactions such as lipid synthesis. NADPH can be produced by the oxidative pentose phosphate pathway, isocitrate dehydrogenase enzymes, malic enzyme, or serine-driven one-carbon metabolism in conjunction with the folate pathway (Fan et al. 2014). The relative importance of each source of NADPH varies depending on the cellular context. For example, RAS activation promotes NADPH production via malic enzyme, whereas loss of p53 enhances NADPH production through malic enzyme and the oxidative pentose phosphate pathway (Jiang et al. 2011, 2013; Son et al. 2013). The redox requirements for biosynthetic reactions have been an area of intense investigation in recent years (Hosios and Vander Heiden 2018). Emerging evidence demonstrates that $\mathrm{NAD}^{+}$can often be limiting for tumor growth, given its essential function in the biosynthesis of macromolecules (e.g., nucleic acids), which are more oxidized than glucose itself (Garcia-Bermudez et al. 2018; Sullivan et al. 2018; Diehl et al. 2019). Because aerobic glycolysis is redox neutral, glycolysis alone provides no means to generate the "extra" oxidized $\mathrm{NAD}^{+}$ molecules required for macromolecular biosynthesis. This necessitates some degree of mitochondrial electron transport chain (ETC) activity to eliminate the excess electrons produced during glycolysis by reduction of molecular oxygen to water, which is coupled to regeneration of $\mathrm{NAD}^{+}$(Birsoy et al. 2015; Sullivan et al. 2015).

To sustain continuous proliferation, cancer cells or subpopulations of cancer stem-like cells must also avoid terminal differentiation (Fig. 1; Intlekofer and Finley 2019). In both leukemia and lymphoma, impaired differentiation frequently results from genetic alterations in chromatin-modifying enzymes (Feinberg et al. 2016). The discovery of somatic isocitrate dehydrogenase $(I D H)$ mutations and the oncometabolite 2-hydroxyglutarate ( $2 \mathrm{HG}$ ) demonstrated that aberrant regulation of specific metabolites or metabolic pathways can directly drive dedifferentiation and "stemness" through inhibitory 
Metabolic Hallmarks of Leukemia and Lymphoma

effects on chromatin-modifying enzymes (Fig. 3; Losman and Kaelin 2013). Whereas succinate, fumarate, and $2 \mathrm{HG}$ can inhibit demethylation reactions, deposition of methyl marks requires $S$-adenosyl-methionine (SAM) produced by the interlinked methionine and folate cycles (Locasale 2013). Likewise, acetyl-CoA derived from glucose, fatty acids, or free acetate regulates acetylation of histones and other proteins, which can influence gene expression and cell differentiation states (Kinnaird et al. 2016). As will be discussed below, recent discoveries have revealed unexpected new connections between the differentiation state of leukemias and lymphomas with the metabolism of branched chain amino acids, alpha-ketoglutarate, cholesterol, and nucleic acids. Thus, the push and pull to meet anabolic proliferative demands can have downstream effects on metabolites and metabolic pathways that influence chromatin dynamics and cell fate decisions.

Given the breadth of diversity within leukemias and the more than 70 different kinds of lymphoma with distinct cells of origin and lineage-specific metabolic networks, it is difficult to make generalizations that apply to all cases. For example, the metabolic features of aggressive acute leukemias and lymphomas differ substantially from indolent, chronic variants. Notably, even among acute leukemias, there are major

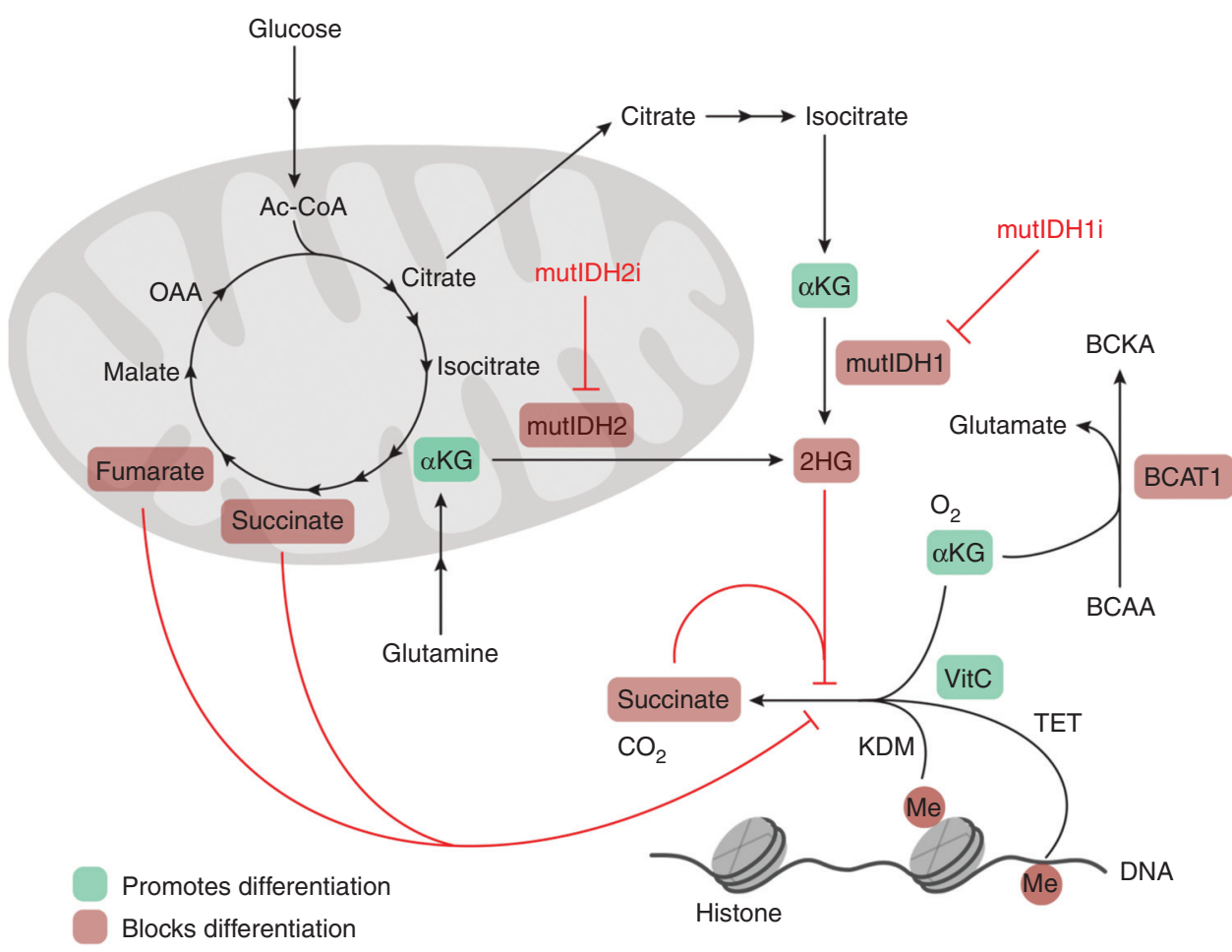

Figure 3. Metabolic inputs into demethylation reactions. Alpha-ketoglutarate ( $\alpha \mathrm{KG}$ ), vitamin $\mathrm{C}$ (VitC)/ascorbate, and oxygen $\left(\mathrm{O}_{2}\right)$ are required for the demethylation of histones and DNA by histone lysine demethylases $(\mathrm{KDM})$ and ten-eleven-translocation (TET) enzymes, respectively. Fumarate, succinate, and 2-hydroxyglutarate (2HG) inhibit demethylases, resulting in accumulation of repressive methyl marks and impaired cell differentiation. Mutations in isocitrate dehydrogenase 1 or 2 (mutIDH1 or mutIDH2) result in enhanced production of $2 \mathrm{HG}$, which can be suppressed by isoform-specific inhibitors (mutIDH1i/mutIDH2i). Overexpression of branched chain amino acid transaminase 1 (BCAT1) results in excessive transfer of $\alpha$-amino groups from branched chain amino acids (BCAA) to $\alpha \mathrm{KG}$, depletion of $\alpha \mathrm{KG}$, decreased demethylase activity, and impaired differentiation. (OAA) Oxaloacetate, (Me) methyl mark, (BCKA) branched-chain alpha-keto acid. 
M. Stahl et al.

differences in the metabolic states of myeloid and lymphoid leukemias, with lymphocyte-specific transcriptional programs conferring an energy-poor metabolic state that must be surmounted for transformation and progression (Müschen 2019). Nonetheless, reprogrammed cancer metabolism generally serves at least four important needs of the cancer cell: (1) bioenergetics, (2) biomass accumulation, (3) redox balance, and (4) differentiation blockade (Fig. 1). In this review, we will discuss these hallmarks of cancer metabolism with a focus on leukemia and lymphoma, highlight their clinical relevance, and outline potential strategies for therapeutic targeting.

\section{LEUKEMIA BIOENERGETICS}

\section{Glycolysis}

Increased glycolysis is a well-recognized hallmark of leukemias (Fig. 2; Boag et al. 2006; Herst et al. 2011; Chen et al. 2014). Oncogenic pathways, such as RAS, MYC, and PI3K/ATK/TOR each induce expression of glucose transporters and glycolytic enzymes and increase glycolytic flux in a wide variety of cancer types, including leukemia and lymphoma (Shim et al. 1997; Osthus et al. 2000; Yun et al. 2009; Coloff et al. 2011; Ying et al. 2012; Poulain et al. 2017). In addition, leukemia-specific genetic alterations, such as BCR-ABL fusions or FLT3 alterations, enhance glycolytic flux and confer oncogenic dependence on glycolysis (Gottschalk et al. 2004; Liu et al. 2014; Ju et al. 2017). Genetic ablation or pharmacologic inhibition of glycolytic machinery, such as glucose transporters, lactate dehydrogenase A (LDHA), or pyruvate kinase M2 (PKM2), can deplete ATP levels, induce cell death, and/or impair proliferation of leukemia cells (Xu et al. 2005; Liu et al. 2014; Wang et al. 2014).

Notably, the B-cell lineage harbors an intrinsic transcriptional program driven by PAX5 and IKZF that suppresses access to glucose and keeps B cells in a relatively energy-poor state compared to myeloid cells (Chan et al. 2017; Martín-Lorenzo et al. 2018; Xiao et al. 2018). Progression of B-cell acute lymphoblastic leukemia (ALL) is associated with genetic events leading to the loss of these transcription factors to allow for increased glucose import, enhanced glycolytic flux, and elevated levels of ATP (Mullighan et al. 2007, 2008; Chan et al. 2017). Interestingly, PTEN deletion in B-cell ALL results in enhanced glucose uptake coupled with excessive kinase activation leading to depletion of cellular ATP stores and cell death, thereby conferring a unique oncogenic dependence on PTEN in B-lineage leukemias (Shojaee et al. 2016).

The importance of glycolysis for leukemogenesis and progression is also evident at the level of systemic glucose metabolism. Epidemiologic studies have identified a direct correlation between hyperglycemia and poor response to chemotherapy in ALL (Weiser et al. 2004). Strikingly, acute myeloid leukemia (AML) was shown to induce production of insulin-like growth factor binding protein 1 (IGFBP1) by adipocytes, resulting in systemic insulin resistance, hyperglycemia, and increased glucose availability for the leukemia cells; interventions aimed at reducing hyperglycemia were able to inhibit leukemic progression (Ye et al. 2018b). Likewise, fasting prevented initiation and progression of B- and T-cell ALL via up-regulation of leptin signaling, which exerted a tumor-suppressive effect ( $\mathrm{Lu}$ et al. 2017). In contrast, a ketogenic diet accelerated leukemic progression in experimental models of AML (Hopkins et al. 2018). This suggests that different dietary strategies to limit systemic glucose availability may have lineage-specific utility or be counteracted by other poorly understood pro-leukemic effects.

The highly glycolytic phenotype of leukemia cells might result in a limited supply of glucose within the bone marrow microenvironment, as significantly lower glucose levels have been measured in leukemic bone marrow compared to peripheral blood (Tiziani et al. 2013). As one strategy to adapt to an insufficient glucose supply, AML cells were shown to enhance fructose uptake by increasing transcription and expression of the GLUT5 fructose transporter, which correlated with inferior survival (Chen et al. 2016). This is of particular importance as high 
Metabolic Hallmarks of Leukemia and Lymphoma

fructose corn syrup, commonly used as a sweetener in processed foods, has been shown to enhance intestinal tumor growth in mice (Goncalves et al. 2019). Of note, pharmacologic inhibition of fructose uptake by AML cells inhibited leukemia growth and synergized with cytarabine chemotherapy (Chen et al. 2016).

Therapeutic targeting of aerobic glycolysis in leukemia has shown minimal success to date. Although 2-deoxyglucose (2-DG) is a useful experimental tool that can inhibit glycolysis and synergize with cytarabine chemotherapy in vitro, it cannot be employed clinically because the high dose of 2-DG required to achieve target inhibition in vivo results in hypoglycemia, as well as cardiac and red blood cell toxicities (Larrue et al. 2015). Furthermore, although highly glycolytic cells appear to be most susceptible to traditional cytotoxic chemotherapies, rare leukemia cell populations dependent on OXPHOS grow out under the pressure of chemotherapy and mediate therapy resistance and relapse (Fig. 4; Farge et al. 2017). More promising results have been shown in AML by targeting altered mitochondrial metabolism, as will be discussed below.

\section{Oxidative Phosphorylation}

In contrast to Warburg's initial hypothesis, it is now well established that mitochondrial oxidative phosphorylation (OXPHOS) is essential for leukemia survival and proliferation. Inhibiting mitochondrial function by disrupting mitochondrial protein synthesis (Škrtić et al. 2011), mitochondrial DNA replication (Liyanage et al. 2017), or mitochondrial protein degradation (Cole et al. 2015) effectively kills leukemia stem cells (LSCs) (Fig. 4). The antimicrobial tigecycline was demonstrated to inhibit mitochondrial translation, resulting in selective elimination of leukemia stem and progenitor cells but not their normal counterparts (Škrtić et al. 2011). Likewise, inhibiting mitochondrial DNA replication in leukemia cell lines and primary AML cells disrupted OXPHOS and induced cell death (Liyanage et al. 2017). The mitochondrial protease ClpP was identified as an important regulator of OXPHOS and mitochondrial metabolism in leukemia cells but not normal cells (Cole et al. 2015). Puzzlingly, although AML cells possess a higher mitochondrial mass compared to normal hematopoietic cells,

\section{A Bulk leukemia}

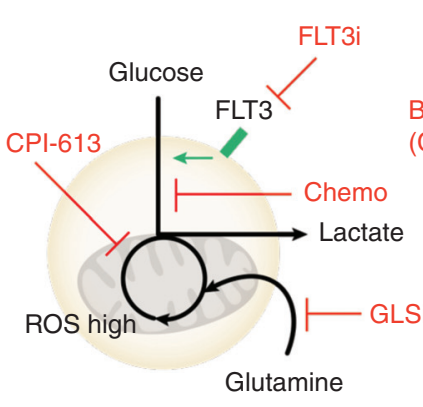

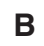

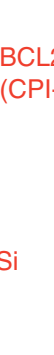

Leukemia stem cells
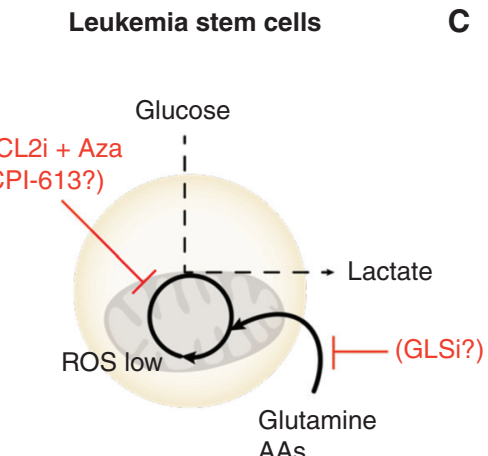

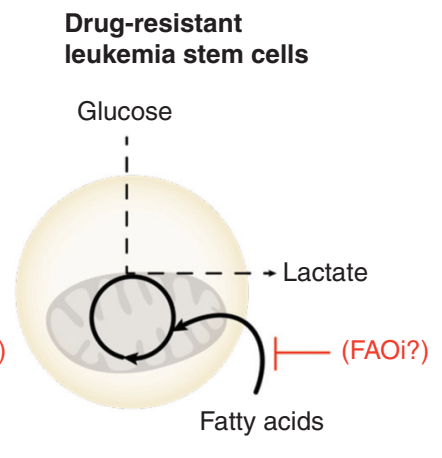

Figure 4. Metabolic vulnerabilities of bulk leukemia and leukemia stem cells. (A) Rapidly dividing bulk leukemia cells exhibit high glycolytic activity and high levels of reactive oxygen species (ROS), whereas (B) quiescent leukemia stem cells exhibit low levels of ROS and depend on mitochondrial oxidation of alternative fuels, such as amino acids (AAs) or fatty acids. Cytotoxic chemotherapies (Chemo) and inhibitors of mutant fms-like tyrosine kinase 3 (FLT3i) target highly glycolytic bulk leukemia cells, but leukemia stem cells are resistant to these therapies and contribute to disease relapse. $(B)$ Mitochondrial metabolism of leukemia stem cells can be targeted by BCL-2 inhibition (BCL2i) in combination with DNA hypomethylating agents, such as azacitidine (Aza). (C) Leukemia stem cells can develop therapeutic resistance by changing their mitochondrial fuel source from AAs to fatty acids. Novel metabolic targeted therapeutics such as inhibitors of glutamine metabolism (GLSi), TCA cycle enzymes (CPI-613), or fatty acid oxidation (FAOi) are under investigation in clinical trials. 
M. Stahl et al.

this does not seem to correspond with an enhanced capacity for respiratory chain complex activity (Sriskanthadevan et al. 2015).

Selective utilization of OXPHOS has also been identified as a key feature of AML cells that are resistant to cytotoxic chemotherapy (Fig. 4; Farge et al. 2017; Baccelli et al. 2019). AML cells resistant to cytarabine treatment in mouse xenografts were found to be primarily reliant on OXPHOS for their survival (Farge et al. 2017), and ETC inhibitors were selectively toxic to a distinct subset of chemotherapy-resistant AML (Baccelli et al. 2019). Furthermore, OXPHOS was demonstrated to be required for tyrosine kinase inhibitor (TKI)-resistant chronic myeloid leukemia (CML) stem cells; inhibition of mitochondrial protein translation with tigecycline in combination with TKIs was able to eliminate these resistant stem cells (Kuntz et al. 2017).

Several recent publications have shown that disrupting OXPHOS by targeting mitochondrial ETC has therapeutic potential in AML. Targeting the ETC complex I with the small-molecule inhibitor IACS-010759 resulted in potent inhibition of proliferation and induction of apoptosis in vitro and improved leukemia-specific survival in mouse models of AML (Molina et al. 2018). These promising preclinical findings resulted in a phase I clinical trial of IACS-010759 for patients with relapsed and treatment-refractory AML (NCT02882321). Additionally, the ERBB2 inhibitor mubritinib, which was recently shown to inhibit ETC complex I activity, exerted significant antileukemic activity against chemotherapy-resistant AML cells with OXPHOS hyperactivity (Baccelli et al. 2019).

The therapeutic benefit achieved by targeting OXPHOS in AML has further been demonstrated by the recently U.S. Federal Drug Administration (FDA)-approved combination of the BCL2 inhibitor venetoclax with the DNA hypomethylating agent azacitidine (DiNardo et al. 2019). This drug combination, which results in unprecedented high response rates, was recently shown to eliminate LSCs by targeting mitochondrial OXPHOS (Fig. 4; Lagadinou et al. 2013; Pollyea et al. 2018; DiNardo et al. 2019). Mechanistically, venetoclax in combination with azacitidine appears to inhibit ETC complex II activity by dis- rupting glutathionylation of succinate dehydrogenase (Pollyea et al. 2018). It was further demonstrated that venetoclax can directly inhibit ETC complex I (Sharon et al. 2019). Additionally, disrupted heme biosynthesis could potentiate venetoclax-induced apoptosis through the loss of ETC activity (Lin et al. 2019). Further clinical evidence for the importance of the ETC in mediating sensitivity of leukemia cells to venetoclax + azacitidine comes from the observation that $I D H$ mutations induce a dependence on BCL2, likely explaining the especially high response rates of IDH-mutated AML to this treatment combination (Chan et al. 2015). Mutant IDH-derived 2HG, among many other effects, inhibited the activity of cytochrome $c$ oxidase (COX) in the ETC, thereby lowering the mitochondrial threshold to trigger apoptosis upon BCL2 inhibition (Chan et al. 2015).

An alternative strategy to inhibit mitochondrial metabolism is to directly interfere with the activity of the TCA cycle. Glutamine depletion or inhibition of glutamine metabolism by blocking the rate-limiting enzyme glutaminase impairs TCA anaplerosis and blocks OXPHOS (Fig. 4; Emadi 2015; Jacque et al. 2015; Matre et al. 2016; Gallipoli et al. 2018; Gregory et al 2018). The lipoic acid analog CPI-613 is a firstin-class TCA cycle inhibitor purported to disrupt lipoylation of pyruvate dehydrogenase $(\mathrm{PDH})$ and $\alpha-\mathrm{KG}$ dehydrogenase (OGDH) (Stuart et al. 2014). CPI-613 showed modest activity in early-phase clinical trials in patients with advanced hematological malignancies (Pardee et al. 2014) and AML (Pardee et al. 2018). CPI-613 is currently being tested in combination with chemotherapy for patients with relapsed/refractory AML in randomized phase III clinical trial (NCT03504410).

\section{Fatty Acid Oxidation}

Fatty acid oxidation (FAO) provides electron donors $\mathrm{NADH}$ and $\mathrm{FADH}_{2}$ to ETC complex I and complex II, respectively, and produces acetyl-CoA, which can be oxidized in the TCA cycle or deposited on histones for regulation of gene expression (Carracedo et al. 2013; Ye et al. 2016; Farge et al. 2017). FAO has been shown to me- 
diate resistance to a variety of antileukemic agents (Fig. 4; German et al. 2016; Jones et al. 2018). Chemotherapy-resistant CML LSCs were demonstrated to induce lipolysis in the gonadal adipose tissue niche and capture free fatty acids through increased expression of the fatty acid transporter CD36 (Ye et al. 2016). Utilizing patient-derived xenograft models of primary human AML, it was shown that the cytarabine-resistant residual AML cells were characterized by high OXPHOS activity, increased FAO, and up-regulated CD36 expression; inhibiting FAO induced an energetic shift toward low OXPHOS status and significantly augmented the antileukemic effects of cytarabine (Farge et al. 2017). Notably, whereas newly diagnosed AML exhibited impressively high response rates to venetoclax + azacitidine, response rates in relapsed/refractory AML were much lower (DiNardo et al. 2019; Bewersdorf et al. 2020). One possible explanation for this observation could be differences in the metabolism of LSCs at diagnosis versus at time of disease relapse (Jones et al. 2018). Treatment-naive LSCs exhibited dependence on amino acid uptake for OXPHOS maintenance and could not up-regulate FAO metabolism to preserve TCA cycle activity, whereas LSCs from patients at the time of relapse were able to compensate for the loss of amino acids by rewiring their metabolism toward FAO (Jones et al. 2018). Several different inhibitors of FAO have exhibited promising activity in preclinical AML models. Inhibition of FAO with the carnitine palmitoyltransferase 1 (CPT1) inhibitor etomoxir induced apoptosis in AML cells, which was synergistic with the BCL2 inhibitor ABT-731 and cytarabine (Samudio et al. 2010). Likewise, a novel CPT1b inhibitor ST1326 (Teglicar) demonstrated significant activity against both AML cell lines and primary samples, in conjunction with a more favorable safety profile (Ricciardi et al. 2015).

\section{LEUKEMIA BIOMASS}

\section{Amino Acids}

Asparaginase exploits the unusual dependency of ALL cells on exogenous supply of the nones-
Metabolic Hallmarks of Leukemia and Lymphoma

sential amino acid asparagine and represents of the best-known metabolic dependencies in cancer (Clavell et al. 1986; Akagi et al. 2006; Williams et al. 2020). Compared to ALL cells, AML cells demonstrate reduced sensitivity to asparagine depletion, and asparaginase is not part of standard therapeutic regimens in AML. Asparaginase resistance in AML appears to be attributable to both variable expression levels of asparagine synthetase (ASNS) levels in AML cells as well as production of cathepsin $B$, a protease that inactivates L-asparaginase, by mesenchymal stromal cells and monocytes/macrophages in the bone marrow microenvironment of AML cells (Michelozzi et al. 2019). Additionally, bone marrow adipocytes have been shown mediate resistance to asparaginase by producing glutamine that can be captured by AML cells (Ehsanipour et al. 2013). However, there has been an intense search for other amino acid dependencies in AML and glutamine, arginine, and cysteine have been shown to represent potential metabolic dependencies in AML, as will be discussed below.

Inhibition of glutamine utilization in leukemia cells by genetic or pharmacological targeting of glutaminase exerted potent antileukemic activity, which could be augmented by chemotherapy (Fig. 4; Jacque et al. 2015). Although FLT3 inhibitors potently down-regulated glycolysis in myeloid leukemia cells, glutamine metabolism remained unaffected (Gallipoli et al. 2018). However, combining FLT3 inhibitors with the glutaminase inhibitor CB-839 resulted in synergistic antileukemic activity (Gallipoli et al. 2018; Gregory et al. 2018). Furthermore, inhibition of glutaminase depleted cellular stores of reduced glutathione, leading to increased mitochondrial ROS and synergistic toxicity when combined with arsenic trioxide (Gregory et al. 2019) or venetoclax (Emadi 2015; Jacque et al. 2015). Likewise, glutaminase inhibition synergized with NOTCH inhibition in T-ALL, although this effect could be counteracted by PTEN loss, which induced a switch to a hyperglycolytic state (Herranz et al. 2015). As an alternative strategy, genetic or pharmacological inhibition of the amino acid transporter ASCT2, whose preferred substrate is glutamine, blocked TOR signaling and induced apoptosis in MLL- 
M. Stahl et al.

AF9-driven leukemia cells ( $\mathrm{Ni}$ et al. 2019). These preclinical findings prompted several clinical trials attempting to target glutamine metabolism in myeloid neoplasms, either alone or in combination with other agents (NCT02071 927; NCT03047993) (Wang et al. 2015b).

Arginine is important for the synthesis of protein, nitric oxide, polyamines, and other amino acids, such as glutamate and proline; cells can either import arginine or synthesize it from citrulline by utilizing argininosuccinate synthetase1 (ASS1) (Szlosarek 2014). A subgroup of AML lacks ASS1 expression and relies on the import of arginine, potentially conferring susceptibility to arginine deprivation therapy (Miraki-Moud et al. 2015). Moreover, AML with overexpression of ecotropic virus integration site 1 protein (EVI1) relies on a functional creatine kinase pathway, which in turn depends on sufficient supply of arginine, to maintain cytosolic ATP levels and mitochondrial OXPHOS activity (Fenouille et al. 2017). Arginine-depleting enzymes, arginine deiminase (ADI-PEG 20) and arginase (BCT-100), demonstrated antileukemic activity in AML models with low or absent expression levels of ASS1 (Miraki-Moud et al. 2015; Mussai et al. 2015). However, when ADI-PEG20 was tested in a phase II trial in RR-AML patients, only 9.5\% of patients achieved a complete response despite almost all pretreatment tumor samples showing ASS1 deficiency (NCT01910012) (Tsai et al. 2017). Somewhat counterintuitively to the above described dependence of AML blasts on arginine for proliferation, AML blasts have also been shown to secrete arginase II leading to inhibition of arginine-dependent $\mathrm{T}$ cells and immune evasion (Mussai et al. 2013).

The combination of venetoclax + azacitidine was shown to decrease amino acid uptake in LSCs, which were uniquely reliant on amino acid metabolism for OXPHOS and survival (Fig. 4; Jones et al. 2018). Whereas the bulk population of leukemia cells were able to adapt to amino acid starvation by increasing FAO to supply TCA cycle intermediates and energy, LSCs appeared to be more metabolically inflexible and unable to compensate for the decreased amino acid uptake induced by venetoclax + azacitidine (Jones et al. 2018). Subsequent studies demonstrated that cysteine was particularly important for the viability of LSCs (Jones et al. 2019). Depletion of cysteine resulted in impaired glutathione synthesis, loss of glutathionylation of succinate dehydrogenase A, impaired ETC complex II activity, and cell death (Jones et al. 2019).

\section{Lipids}

Rapidly dividing leukemia cells need to meet the high demand for phospholipids, cholesterol, and triglycerides required for the synthesis of cell membrane structures (Currie et al. 2013). Apoptosis of AML cells can be induced by inhibiting the lipogenic enzymes fatty acid synthase (FASN) and stearoyl CoA desaturase 1 (SCD1) (Pizer et al. 1996; Khanim et al. 2009; Southam et al. 2015). However, in a phase I trial testing combination of lipid-regulating bezafibrate and the sex hormone medroxyprogesterone acetate, which was shown to inhibit SCD1, only one of 19 patients with AML achieved a partial response (Murray et al. 2010).

Several studies have focused on redeploying statins as anticancer therapy after an antileukemic effect of statin drugs was recognized early on in AML (Newman et al. 1994; Clutterbuck et al. 1998; Dimitroulakos et al. 2000). Statins inhibit HMG-CoA reductase, the rate-limiting enzyme of the mevalonate pathway that produces cholesterol, ubiquinone, dolichol, and geranylgeranyl/farnesyl pyrophosphate (Wong et al. 2002). Although some early-phase nonrandomized clinical trials showed some encouraging response rates when combining pravastatin with idarubicin and cytarabine in patients with relapsed/refractory AML, a similar trial in the up-front treatment setting was unable to confirm these results (Kornblau et al. 2007; Shadman et al. 2015; Advani et al. 2018). It is possible the differential activity was due to alterations in cholesterol and lipid metabolism induced by prior chemotherapy, as described above (Kornblau et al. 2007; Shadman et al. 2015; Farge et al. 2017; Advani et al. 2018). Recently, statins were shown to prime leukemia and lymphoma cells for venetoclax-mediated apoptosis via suppressed protein geranylgeranylation, resulting in induction of the proapoptotic protein p53 
up-regulated modulator of apoptosis (PUMA) (Lee et al. 2018). In a retrospective multivariate regression analysis of three studies examining venetoclax in patients with chronic lymphocytic leukemia (CLL), statins were associated with significantly increased odds of attaining a complete response (OR 2.68, $P=0.0054$ ) (Lee et al. 2018).

\section{Nucleotides}

Mitochondrial electron transport function plays a vital role in regenerating $\mathrm{NAD}^{+}$to enable aspartate production and nucleotide biosynthesis (Birsoy et al. 2015; Sullivan et al. 2015, 2018; Garcia-Bermudez et al. 2018). The sensitivity to ETC inhibition varied across cancer cell lines, with cell lines resistant to ETC inhibition being able to maintain aspartate levels by import through the aspartate-glutamate transporter SLC1A3 (Garcia-Bermudez et al. 2018). Because ETC inhibition is under investigation as a promising antileukemic therapy (venetoclax and IACS-01075), the ability of a leukemic cell to maintain aspartate levels in response to ETC inhibition may determine sensitivity to this treatment strategy. Indeed, antileukemic activity of IACS-01075 was associated with reduced aspartate production and impaired nucleotide biosynthesis (Molina et al. 2018).

Antimetabolites, which mimic purines (e.g., fludarabine, 6-MP) or pyrimidines (e.g., cytarabine) required for DNA synthesis or interfere with folate-dependent nucleotide synthesis (e.g., methotrexate), represent the oldest effective treatments for leukemia (Farber and Diamond 1948). Modern genetic studies have confirmed the importance of nucleotide biosynthesis in leukemia. For example, ablation of methylenetetrahydrofolate dehydrogenase-cyclohydrolase 2 (MTHFD2), a key enzyme in the one-carbon folate metabolism and purine synthesis, inhibited leukemic growth and promoted differentiation of AML blasts in vivo (Pikman et al. 2016). Thiopurine-resistant ALL acquired gain-of-function mutations in the enzyme NT5C2, which facilitates removal of toxic nucleotide intermediates that build up in the context of thiopurine treatment; notably, NTC52 mutations created a new vulnerability to inosine- $5^{\prime}$-monophosphate de- hydrogenase (IMPDH) inhibition (Meyer et al. 2013; Tzoneva et al. 2013, 2018; Dieck et al. 2018). Utilizing a large drug screening approach, inhibition of dihydro-orotate dehydrogenase (DHODH) with brequinar sodium was found to inhibit leukemia growth by promoting myeloid differentiation of AML blasts (Sykes et al. 2016). $\mathrm{DHODH}$ is a mitochondrial enzyme that catalyzes the ubiquinone-mediated conversion of dihydro-orotate to orotate in the pyrimidine biosynthetic pathway. Based on this promising preclinical activity, multiple DHODH inhibitors are being tested in early phase clinical trials for a variety of myeloid malignancies (Sykes et al. 2016; Ladds et al. 2018; Wu et al. 2018b; Cao et al. 2019; Christian et al. 2019).

\section{LEUKEMIA REDOX}

Conventional chemotherapy induces redox stress in the form of ROS (Trachootham et al. 2009). Significant differences in ROS levels distinguish the rapidly dividing bulk population of leukemia cells from quiescent LSCs, which have been proposed to drive chemotherapy resistance and relapse (Lagadinou et al. 2013). Functionally defined LSCs exhibited relatively low levels of ROS, increased BCL2 expression, and dependence on OXPHOS for survival (Lagadinou et al. 2013). Treatment of AML LSCs with the BCL2 inhibitor venetoclax in combination with azacitidine resulted in depletion of cysteine and the antioxidant glutathione, leading to increased ROS levels and disruption of ETC complex II function (Pollyea et al. 2018; DiNardo et al. 2019; Jones et al. 2019). Alternative strategies to disrupt cysteine metabolism can deplete intracellular pools of reduced glutathione, increased ROS, and blocked growth of CLL (Zhang et al. 2012; Cramer et al. 2017). Likewise, targeting the pentose phosphate pathway, an important source of NADPH for buffering oxidative stress, displayed antileukemic activity toward chemoresistant AML (Bhanot et al. 2017; Poulain et al. 2017).

\section{LEUKEMIA DIFFERENTIATION}

The discovery of leukemia-associated mutations in IDH enzymes provided seminal insights into 
M. Stahl et al.

the interplay between metabolism, epigenetics, and differentiation (Dang et al. 2009; Mardis et al. 2009; Ward et al. 2010). Mutant IDH enzymes lose normal enzyme function and gain the ability to produce the oncometabolite 2HG. 2HG inhibits the function of $\alpha$ KG-dependent chromatin-modifying enzymes, resulting in blockade of myeloid differentiation (Fig. 3; Figueroa et al. 2010; Lu et al. 2012; Turcan et al. 2012; Rohle et al. 2013; Wang et al. 2013; Yen et al. 2017). In addition, $2 \mathrm{HG}$ can inhibit the function of enzymes involved in RNA demethylation, DNA repair, hypoxia-inducible factor (HIF) stability, collagen maturation, and intermediary metabolism (Koivunen et al. 2012; Chan et al. 2015; Fu et al. 2015; Wang et al. 2015c; Sulkowski et al. 2017, 2020; McBrayer et al. 2018; Su et al. 2018). Because some of effects of $2 \mathrm{HG}$ can be tumor-suppressive, the net effect of $I D H$ mutations and 2HG in a given cell lineage likely depends on the balance of oncogenic and tumor-suppressive activities (Elkashef et al. 2017; Ye et al. 2018a). Importantly, small-molecule inhibitors of mutant IDH enzymes can suppress $2 \mathrm{HG}$ production, restore myeloid differentiation, and induce clinical responses in $\sim 40 \%$ of patients with relapsed/ refractory $I D H$-mutant AML, leading to their recent FDA approvals for this indication (Fig. 3; Stein et al. 2017; DiNardo et al. 2018).

The branched chain amino acid amino transferase 1 (BCAT1) also influences $\alpha \mathrm{KG} \mathrm{lev-}$ els and has been shown to regulate leukemogenesis and leukemia cell differentiation (Hattori et al. 2017; Raffel et al. 2017). In AML, overexpression of BCAT1 caused excessive transfer of $\alpha$-amino groups from branched chain amino acids (BCAAs) to $\alpha \mathrm{KG}$, resulting in depletion of $\alpha K G$ stores, DNA hypermethylation, and impaired myeloid differentiation (Fig. 3; Raffel et al. 2017). This BCAT1-mediated mechanism can mimic the epigenetic effects of $2 \mathrm{HG}$ in $\mathrm{IDH}$ wild-type AML. In contrast, in CML blast crisis, overexpression of BCAT1 promoted excessive conversion of branched chain keto acids to BCAAs, which promoted leukemogenesis through TOR activation (Hattori et al. 2017).

Vitamin $\mathrm{C}$, or ascorbate, functions as an essential cofactor for a variety of $\alpha \mathrm{KG}$ - and
$\mathrm{Fe}^{2+}$-dependent enzymes, including TET enzymes involved in DNA demethylation (Fig. 3; Cimmino et al. 2018). Vitamin C promoted enhanced TET activity, promoted DNA demethylation, and restored differentiation in models of myeloid leukemia (Agathocleous et al. 2017; Cimmino et al. 2017). Vitamin C may also act by depleting glutathione and increasing ROS levels (Yun et al. 2015). It remains unclear whether vitamin C could be used clinically-for example, as a preventative strategy in TET2-mutant clonal hematopoiesis (Huijskens et al. 2016). Notably, prior attempts to use vitamin $\mathrm{C}$ as an antineoplastic agent were not successful (Moertel et al. 1985), but more recent work suggests that vitamin $\mathrm{C}$ may be effective in KRAS/RAF-mutant cancers (Yun et al. 2015). The vitamin B6 pathway was also recently identified as a metabolic dependence in AML; perturbation of the pathway with isoniazid resulted in antileukemic activity in vivo (Chen et al. 2020).

\section{LYMPHOMA BIOENERGETICS}

\section{Glycolysis}

Enhanced glycolysis in lymphoma is evident from the utility of fluorodeoxyglucose positron emission tomography (FDG PET) scans for staging and response assessment and the use of blood LDH levels for prognostication (Seam et al. 2007; Sehn et al. 2007). The degree of glucose uptake, as measured by FDG avidity, effectively distinguishes indolent and aggressive forms of lymphoma (Noy et al. 2009). Aggressive forms of B-cell lymphoma exhibit aberrant overexpression of MYC, either through chromosomal translocations or transcriptional deregulation (Stine et al. 2015). Numerous studies have demonstrated that MYC enhances glycolytic flux through direct transactivation of glucose transporters (GLUT1), glycolytic enzymes (e.g., PFK, enolase), and LDHA (Shim et al. 1997; Osthus et al. 2000). In a model of Burkitt lymphoma with inducible control of MYC expression, MYC drove Warburg-like aerobic glycolysis with increased glucose consumption and lactate production (Le et al. 2012). This effect of MYC was counteracted by the activity of the 
energy-stress kinase AMPK, as deletion of AMPK accelerated MYC-induced lymphomagenesis (Faubert et al. 2013). Both PI3K/AKT/ TOR and NF- $\kappa \mathrm{B}$ signaling can cooperate with MYC to enhance GLUT1 transporter expression and transport to the cell surface (Sommermann et al. 2011; Bhatt et al. 2012; Broecker-Preuss et al. 2017). Epstein-Barr virus (EBV)-driven lymphomagenesis is characterized by an initial energy-poor state sustained by autophagy with progression of disease associated with up-regulation of the GLUT1 transporter and increased glycolytic flux (Bhatt et al. 2012; McFadden et al. 2016). In addition, targeting glucose uptake and/or glycolysis was demonstrated to abolish MCL-1 expression and overcome resistance to BCL2 inhibitors in DLBCL (Coloff et al. 2011).

The glycolytic enzyme glyceraldehyde 3-phosphate dehydrogenase (GAPDH) has been identified as a metabolic marker of aggressive DLBCL, irrespective of MYC expression (Chiche et al. 2015). Despite having more aggressive pathologic features, DLBCL with high expression of GAPDH predicted for better outcomes in response to R-CHOP chemotherapy (Chiche et al. 2019). In contrast, GAPDH-low DLBCL produced less ATP from glycolysis, preferentially used mitochondrial OXPHOS, and exhibited higher TOR activity. Several patients with GAPDH-low DLBCL responded to a combination of metabolic agents, including asparaginase, temsirolimus (TOR inhibitor), and metformin (ETC complex I inhibitor). In contrast to GAPDH, overexpression of glycolytic enzyme hexokinase 2 (HK2) was shown to mediate therapeutic resistance in DLBCL and ablation of HK2 inhibited lymphoma growth $(\mathrm{Gu}$ et al.2018). Interestingly, the histone deacetylase (HDAC) inhibitor panobinostat was shown to diminish HK2 expression and restore platinum chemosensitivity in DLBCL cells (Nakajima et al. 2019).

Diabetes has been associated with increased risk of non-Hodgkin lymphoma (NHL), possibly because of increased glucose availability for lymphoma cells (Mitri et al. 2008; Castillo et al. 2012). Compounds targeting glucose uptake pathways in cancer cells have yet to demonstrate viability for clinical practice as a result of unac- ceptably low target specificity (Montrose and Galluzzi 2019). However, emerging evidence suggests that glucocorticoids may act, at least in part, through inhibition of glucose uptake by malignant lymphoid cells (Holleman et al. 2004; Hulleman et al. 2009; Chan et al. 2017).

\section{Oxidative Phosphorylation}

Numerous studies have demonstrated that DLBCL can be segregated into distinct subtypes based on mitochondrial OXPHOS activity (Fig. 5; Monti et al. 2005; Caro et al. 2012). Mechanistic studies found that the OXPHOS subset of DLBCL had increased activity of and dependence on mitochondrial FAO. Intriguingly, when B-cell receptor (BCR) signaling was inhibited in other subtypes of DLBCL, there was a shift from glycolysis to increased FAO, suggesting that this might represent a metabolic mechanism of adaptation and/or resistance to targeted therapies in DLBCL (Fig. 5; Caro et al. 2012). Recent investigations demonstrated that the genes involved in OXPHOS (e.g., ETC complexes I, III, IV, V) were largely dependent on MYC for translation (Singh et al. 2019). Another line of evidence supports a role for glutamine-dependent OXPHOS as a mediator of ibrutinib resistance in mantle cell lymphoma (MCL), potentially driven by MYC and TOR activity (Lee et al. 2019; Zhang et al. 2019a). Ibrutinib-resistant MCL was uniquely dependent on glutamine uptake and glutaminolysis; disruption of glutamine metabolism or ETC complex I increased ROS, induced energetic stress, and overcame resistance to ibrutinib. Enhanced OXPHOS was recently identified as a mechanism of resistance to the BCL2 inhibitor venetoclax in lymphoma, and treatment with ETC inhibitors restored sensitivity to venetoclax (Chukkapalli et al. 2018; Guièze et al. 2019).

\section{LYMPHOMA BIOMASS}

\section{Amino Acids}

MYC drives glutamine uptake and glutaminolysis (Stine et al. 2015). In MYC-driven lymphomas, MYC-induced expression of the glutamine 
M. Stahl et al.
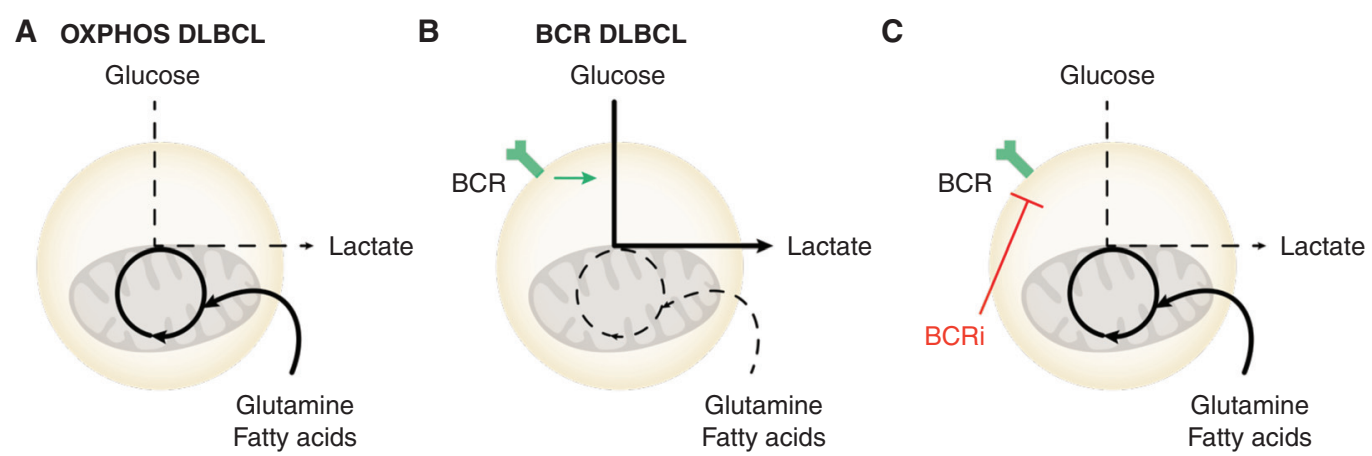

Figure 5. Metabolic subtypes of diffuse large B cell lymphoma (DLBCL). Gene expression and metabolic profiling distinguishes subtypes of DLBCL based on activity of and dependency on mitochondrial oxidative phosphorylation (OXPHOS). (A) OXPHOS DLBCL exhibits relatively low glycolytic flux and enhanced mitochondrial oxidation of glutamine and fatty acids. (B) B-cell receptor (BCR) DLBCL exhibits enhanced glycolytic flux and limited mitochondrial OXPHOS. $(C)$ Inhibition of BCR signaling (BCRi) in BCR DLBCL results in decreased glycolysis and increased mitochondrial OXPHOS as a putative adaptive response.

transporters SLC7A5 and SLC1A5 and relieved microRNA-mediated inhibition of glutaminase expression (Gao et al. 2009). Glutamine deprivation depleted TCA cycle intermediates, ATP, and glutathione, resulting in lymphoma cell death (Gao et al. 2009). Likewise, in MYC-driven Burkitt lymphoma, glutamine deprivation activated the integrated stress response (e.g., GCN2-elF2 $\alpha$, ATF4) and proapoptotic pathways (e.g., PUMA, NOXA, BAX) (Qing et al. 2012). Additional evidence demonstrated that DLBCL requires the mitochondrial lysine deacetylase SIRT3 to maintain glutamine flux into the TCA cycle via glutamate dehydrogenase (Li et al. 2019).

In addition to $M Y C$, direct mutations in genes that mediate amino acid sensing have been identified in follicular lymphoma (FL) (Okosun et al. 2016; Ying et al. 2016). Approximately $17 \%$ of patients with FL harbored mutations in RRAGC, which encodes for RagC. RagC normally forms a complex with Ragulator, V-ATPase, and SLC38A9 to activate TOR in response to amino acids. Lymphoma-associated RRAGC mutants aberrantly activated TOR even in conditions of amino acid deprivation, relieved dependency on activation/stimulation signals from $\mathrm{CD}^{+} \mathrm{T}$ cells, and conferred heightened sensitivity to TOR inhibitors (Ortega-Molina et al. 2019; Wang et al. 2019a). FL also harbors mutations in ATP6V1B2 (V-ATPase subunit) or deletions of SESTRIN1 (negative regulator of
TOR), which analogously function to stimulate aberrant TOR activity (Oricchio et al. 2017; Ortega-Molina et al. 2019; Wang et al. 2019a).

Analogous to its application in ALL, asparaginase demonstrates selective activity for natural killer (NK)-cell lymphoma, a relatively rare and aggressive form of EBV-driven lymphoma that depends on exogenous asparagine for survival (Chien et al. 2015; d'Amore et al. 2015). Asparagine depletion activated the integrated stress response (GCN2/elF2 $\alpha / \mathrm{ATF} 4)$ and suppressed TOR activity, but failure to activate ATF-mediated ASNS expression and increase asparaginase synthesis resulted in cell death (Bunpo et al. 2009; Ye et al. 2010; Chien et al. 2015). Response to asparaginase was further associated with proteolytic cleavage of BCL2A1, which converted it from an antiapoptotic to a proapoptotic factor (Chien et al. 2015). Loss of critical genes involved in polyamine metabolism (AMD1, eIF5A) was shown to promote lymphomagenesis, suggesting that metabolism of amino acids in the urea cycle can exert tumor-suppressive effects in some lymphomas (Scuoppo et al. 2012).

\section{Lipids}

Up-regulated lipid synthesis has been observed across a range of lymphoma types, which can create a therapeutic vulnerability to fatty acid 
synthase inhibitors (Bhatt et al. 2012). Lipid droplets have long been recognized as a pathologic hallmark of Burkitt lymphoma, the prototypical MYC-driven cancer (Morrish et al. 2010; Ambrosio et al. 2012; Eberlin et al. 2014). Mechanistically, MYC induces the transcription factor sterol-regulated element-binding protein (SREBP1) and cooperates with SREBP1 to drive expression of key enzymes involved in fatty acid synthesis, fatty acid elongation, and phospholipid synthesis; these effects were coordinated with MYC-induced glycolysis and glutaminolysis to provide acetyl-CoA building blocks for lipid synthesis (Southam et al. 2015; Gouw et al. 2019). Similarly, MYC was shown to induce phosphocholine synthesis in DLBCL through transcriptional activation of PCYT1A (Xiong et al. 2017). Inhibition of lipid synthesis impaired growth of MYC-dependent lymphomas (Xiong et al. 2017; Gouw et al. 2019). Cholesterol metabolism offers a potential vulnerability for some lymphomas. For example, $\mathrm{ALK}^{+}$anaplastic large cell lymphoma (ALCL) lacks expression of squalene monooxygenase (SQLE), which catalyzes the ratelimiting step of cholesterol synthesis (GarciaBermudez et al. 2019). Thus, ALK ${ }^{+}$ALCL cells were functionally auxotrophic for exogenous cholesterol and inhibition of cholesterol import was a therapeutic vulnerability. Interestingly, loss of SQLE was suggested to confer a fitness advantage by allowing accumulation of squalene, which could block ferroptotic cell death in response oxidative stress (Garcia-Bermudez et al. 2019).

\section{Nucleotides}

Nucleotide synthesis represents another therapeutic vulnerability in lymphomas, as evidenced by the long-standing use of methotrexate and pralatrexate in these diseases. Targeted inhibition of serine hydroxymethyltransferases 1 and 2 (SHMT1/2), key enzymes in serine-driven one-carbon folate metabolism, impeded purine biosynthesis, disrupted DNA/histone methylation, and arrested B-cell lymphoma proliferation; concurrent glycine restriction and/or inhibition of glycine uptake augmented this ef-
Metabolic Hallmarks of Leukemia and Lymphoma

fect (Ducker et al. 2017; Parsa et al. 2020). EBVdriven lymphomas exhibit increased uptake of serine and glycine and enhanced metabolic flux through the one-carbon folate pathway for nucleotide biosynthesis (Wang et al. 2019b, 2019c). These effects appear to be driven by the EBV protein EBNA2, and targeting one-carbon folate metabolism via inhibition of SHTM1/2 markedly decreased EBV-driven B-cell lymphoproliferation.

\section{LYMPHOMA REDOX}

Increased ETC activity created a potential metabolic vulnerability from mitochondrial ROS, such that OXPHOS DLBCL cells were particularly sensitive to depletion of antioxidants (Norberg et al. 2017). In a variety of B- and T-cell lymphoma lines, inhibition of ETC complex I by metformin or other agents increased ROS and impaired mitochondrial oxygen consumption (Khan et al. 2019). Mitochondrial ROS stabilized hypoxia-inducible factor (HIF) and increased glycolytic flux and glucose dependence; concomitant ablation of HIF induced cell death (Khan et al. 2019). Ferroptosis, a form of programmed cell death triggered by lipid peroxidation, could be induced in DLBCL cells by targeted inhibition of the cystine-glutamine antiporter xCT (Zhang et al. 2019b). In ALCL, oxidative stress induced a reversion to a more stem-like state driven by activation of the WNT/ $\beta$-catenin signaling; inhibiting WNT signaling reversed this effect and overcame chemoresistance (Wu et al. 2018a). In B-cell lymphomas and leukemias, the pentose phosphate pathway was shown to play a critical role in generating NADPH to buffer oxidative stress. For this reason, B-cell malignancies exhibited a unique dependency on the phosphatase PP2A, which inhibits PFK2B, limits production of fructose-2,6-bisphosphate, and ensures adequate glycolytic flux through glucose-6-phosphate dehydrogenase (G6PD) and the pentose phosphate shunt (Xiao et al. 2018). This created a therapeutic vulnerability such that combined inhibition of PP2A and G6PD dramatically depleted NADPH and glutathione pools, increased ROS, and synergized in lymphoma cell killing. 
M. Stahl et al.

\section{LYMPHOMA DIFFERENTIATION}

Of all lymphoid malignancies, only angioimmunoblastic T-cell lymphoma (AITL) exhibits recurrent mutations in IDH enzymes (Cairns et al. 2012; Wang et al. 2015a). IDH2-mutant AITL exhibited decreased 5-hydoxymethylcytosine and increased 5-methylcytosine because of inhibition of TET enzymes by the oncometabolite 2 HG. Likewise, histone methylation was enhanced in IDH2-mutant versus wild-type cases. In mouse models, IDH2 mutations were shown to impair T lymphocyte development and differentiation, decreasing thymocyte numbers and skewing mature $\mathrm{T}$ cells toward memory phenotypes (Lemonnier et al. 2016). This suggests that $\mathrm{IDH} 2$ mutations may cause an arrest in T-cell development, analogous to the stemness promoting effects of $I D H$ mutations in AML. Enzymes that regulate TCA cycle metabolites have also been explored in DLBCL, in which $9 \%$ of 69 tumor samples were shown to have loss-of-function mutations of the 2HGdisposal enzyme D2HGDH (Lin et al. 2015). Loss of D2HGDH was associated with increased $2 \mathrm{HG}$ and decreased $\alpha \mathrm{KG}$ levels, which increased repressive methylation of histones and DNA. However, further work is needed to determine whether $2 \mathrm{HG}$ metabolism offers a viable therapeutic target in lymphomas.

\section{CONCLUDING REMARKS}

We have described how leukemias and lymphomas rewire metabolism to support rapid cell growth and proliferation and, in some cases, couple this to dedifferentiation and self-renewal. Investigations into blood cancer metabolism have led to promising new therapies that target mitochondrial oxidative function, mutant IDH enzymes, pyrimidine biosynthesis, or serine production. Furthermore, long-standing metabolically targeted therapies such as methotrexate remain cornerstones of treatment for many patients with leukemias and lymphomas. As novel therapies advance further in clinical development with concurrent laboratory-based studies, important new insights will be made into the mechanisms by which targeting cancer cell me- tabolism can exert pleotropic downstream effects. For example, it remains unclear how targeting specific metabolic pathways apparently involved in biosynthetic processes triggers differentiation in leukemia, such as DHODH.

Of particular interest are those metabolically targeted therapies that can specifically target cancer stem cells, which are hypothesized to drive resistance to conventional treatments and contribute to disease relapses. Why LSCs appear to be particularly dependent on mitochondrial oxidative metabolism remains unclear. It is possible that these cancer stem cells reside in microenvironmental niches with restricted access to glucose, necessitating the use of alternative fuels such as amino acids or fatty acids that can only generate ATP through mitochondrial oxidation. Because LSCs are not highly proliferative, they might not depend on the high glycolytic flux and Warburg-like metabolism required for rapidly doubling biomass. This would also make them inherently resistant to most conventional therapies that target macromolecular biosynthetic pathways, in particular nucleic acid biosynthesis and DNA replication. However, to truly understand the metabolic state of LSCs, new technologies that allow for in situ assessments of metabolite levels, metabolic flux, and mitochondrial function will be required.

Another emerging realm of importance is the complex interplay between cancer cell metabolism, the tumor microenvironment, and antitumor immune responses. For example, $2 \mathrm{HG}$ and lactate have been demonstrated to disrupt antitumor T-cell differentiation (Brand et al. 2016; Xia et al. 2017; Bunse et al. 2018), whereas lactate can also promote differentiation of suppressive macrophages (Colegio et al. 2014). Likewise, tumor microenvironmental factors, such as hypoxia and acidic $\mathrm{pH}$, can disrupt T-cell differentiation and function (Eil et al. 2016). In addition to the emerging roles of lactate and other metabolites as immunoregulatory molecules, new in vivo metabolic tracing methodologies revealed the surprising discovery that circulating lactate functions as the major mitochondrial fuel for most normal and malignant cells (Hensley et al. 2016; Hui et al. 2017). Al- 
though these findings have yet to be confirmed in blood cancers, it is conceivable that the unique dependency of LSCs on OXPHOS could, at least in part, be related to preferential oxidation of lactate.

Otto Warburg's early intuition regarding the importance of tumor metabolism has been validated by the recent explosion of scientific discoveries in this area. Nonetheless, significant work remains to successfully translate these discoveries into therapies that improve outcomes for patients. Future efforts will focus on identifying cancer-specific metabolic dependencies, such that targeting of these pathways does not cause prohibitive toxicities toward normal cells. These endeavors will require sophisticated new techniques to unravel complex and dynamically changing metabolic programs within specific cell populations in vivo. Despite the complexity of cancer metabolism and the challenges associated with manipulating these processes for therapeutic benefit, the future of metabolism research in leukemia and lymphoma appears bright. To paraphrase Anthelme Brillat-Savarin, who in 1825 wrote in his celebrated book The Physiology of Taste, "Tell me what you eat and I will tell you what you are"; indeed, investigating the metabolic circuitry of leukemia and lymphoma cells will both provide fundamental insights about cancer biology and guide development of novel therapeutic approaches to improve outcomes for these diseases.

\section{ACKNOWLEDGMENTS}

We thank Lydia Finley, Santosh Vardhana, and Juanma Schvartzman for helpful discussions. M.S. is supported by the Conquer Cancer Foundation of ASCO Young Investigator Award. Z.D.E.-P. is supported by the American Association for Cancer Research-AstraZeneca Lymphoma Research Fellowship. A.M.I. is supported by the National Institutes of Health (NIH)/National Cancer Institute (NCI) (K08 CA201483, R37 CA251543), Burroughs Wellcome Fund (CAMS 1015584), Damon Runyon Cancer Research Foundation (CI 95-18), Leukemia \& Lymphoma Society (SCOR 7011-16), Starr Cancer Consortium, Geoffrey Beene Can-
Metabolic Hallmarks of Leukemia and Lymphoma

cer Research Foundation, Cycle for Survival, Susan \& Peter Solomon Divisional Genomics Program, and Steven A. Greenberg Fund. The authors are also grateful for support from the Memorial Sloan Kettering Cancer Center Support Grant (NIH P30 CA008748).

Disclosures: A.M.I. previously consulted for Foundation Medicine, Inc.

\section{REFERENCES}

Advani AS, Li H, Michaelis LC, Medeiros BC, Liedtke M, List AF, O’Dwyer K, Othus M, Erba HP, Appelbaum FR. 2018. Report of the relapsed/refractory cohort of SWOG S0919: A phase 2 study of idarubicin and cytarabine in combination with pravastatin for acute myelogenous leukemia (AML). Leuk Res 67: 17-20. doi:10.1016/j.leukres .2018 .01 .021

Agathocleous M, Meacham CE, Burgess RJ, Piskounova E, Zhao Z, Crane GM, Cowin BL, Bruner E, Murphy MM, Chen W, et al. 2017. Ascorbate regulates haematopoietic stem cell function and leukaemogenesis. Nature 549: 476-481. doi:10.1038/nature23876

Akagi T, Yin D, Kawamata N, Bartram CR, Hofmann WK, Wolf I, Miller CW, Koeffler HP. 2006. Methylation analysis of asparagine synthetase gene in acute lymphoblastic leukemia cells. Leukemia 20: 1303-1306. doi:10.1038/sj .leu.2404216

Altman BJ, Dang CV. 2012. Normal and cancer cell metabolism: Lymphocytes and lymphoma. FEBS J 279: 25982609. doi:10.1111/j.1742-4658.2012.08651.x

Ambrosio MR, Piccaluga PP, Ponzoni M, Rocca BJ, Malagnino V, Onorati M, De Falco G, Calbi V, Ogwang M, Naresh KN, et al. 2012. The alteration of lipid metabolism in Burkitt lymphoma identifies a novel marker: Adipophilin. PLoS One 7: e44315. doi:10.1371/journal.pone .0044315

Baccelli I, Gareau Y, Lehnertz B, Gingras S, Spinella JF, Corneau S, Mayotte N, Girard S, Frechette M, BlouinChagnon V, et al. 2019. Mubritinib targets the electron transport chain complex I and reveals the landscape of OXPHOS dependency in acute myeloid leukemia Cancer Cell 36: 84-99.e8. doi:10.1016/j.ccell.2019.06.003

Bahr C, von Paleske L, Uslu VV, Remeseiro S, Takayama N, Ng SW, Murison A, Langenfeld K, Petretich M, Scognamiglio R, et al. 2018. A $M y c$ enhancer cluster regulates normal and leukaemic haematopoietic stem cell hierarchies. Nature 553: 515-520. doi:10.1038/nature25193

Bewersdorf JP, Giri S, Wang R, Williams RT, Tallman MS, Zeidan AM, Stahl M. 2020. Venetoclax as monotherapy and in combination with hypomethylating agents or low dose cytarabine in relapsed and treatment refractory acute myeloid leukemia: A systematic review and meta-analysis. Haematologica doi:10.3324/haematol.2019.242826.

Bhanot H, Weisberg EL, Reddy MM, Nonami A, Neuberg D, Stone RM, Podar K, Salgia R, Griffin JD, Sattler M. 2017. Acute myeloid leukemia cells require 6-phosphogluconate dehydrogenase for cell growth and NADPH-depen- 
M. Stahl et al.

dent metabolic reprogramming. Oncotarget 8: 6763967650. doi:10.18632/oncotarget.18797

Bhatt AP, Jacobs SR, Freemerman AJ, Makowski L, Rathmell JC, Dittmer DP, Damania B. 2012. Dysregulation of fatty acid synthesis and glycolysis in non-Hodgkin lymphoma. Proc Natl Acad Sci 109: 11818-11823. doi:10.1073/pnas .1205995109

Birsoy K, Wang T, Chen WW, Freinkman E, Abu-Remaileh M, Sabatini DM. 2015. An essential role of the mitochondrial electron transport chain in cell proliferation is to enable aspartate synthesis. Cell 162: 540-551. doi:10 .1016/j.cell.2015.07.016

Boag JM, Beesley AH, Firth MJ, Freitas JR, Ford J, Hoffmann K, Cummings AJ, de Klerk NH, Kees UR. 2006. Altered glucose metabolism in childhood pre-B acute lymphoblastic leukaemia. Leukemia 20: 1731-1737. doi:10 $.1038 /$ sj.leu.2404365

Brand A, Singer K, Koehl GE, Kolitzus M, Schoenhammer G, Thiel A, Matos C, Bruss C, Klobuch S, Peter K, et al. 2016. LDHA-associated lactic acid production blunts tumor immunosurveillance by T and NK cells. Cell Metab 24: 657-671. doi:10.1016/j.cmet.2016.08.011

Broecker-Preuss M, Becher-Boveleth N, Bockisch A, Dührsen U, Müller S. 2017. Regulation of glucose uptake in lymphoma cell lines by c-MYC- and PI3K-dependent signaling pathways and impact of glycolytic pathways on cell viability. J Transl Med 15: 158. doi:10.1186/s12967017-1258-9

Bunpo P, Dudley A, Cundiff JK, Cavener DR, Wek RC, Anthony TG. 2009. GCN2 protein kinase is required to activate amino acid deprivation responses in mice treated with the anti-cancer agent L-asparaginase. J Biol Chem 284: 32742-32749. doi:10.1074/jbc.M109.047910

Bunse L, Pusch S, Bunse T, Sahm F, Sanghvi K, Friedrich M, Alansary D, Sonner JK, Green E, Deumelandt K, et al. 2018. Suppression of antitumor T cell immunity by the oncometabolite (R)-2-hydroxyglutarate. Nat Med 24: 1192-1203. doi:10.1038/s41591-018-0095-6

Cairns RA, Iqbal J, Lemonnier F, Kucuk C, de Leval L, Jais JP, Parrens M, Martin A, Xerri L, Brousset P, et al. 2012. IDH2 mutations are frequent in angioimmunoblastic Tcell lymphoma. Blood 119: 1901-1903. doi:10.1182/ blood-2011-11-391748

Cao L, Weetall M, Trotta C, Cintron K, Ma J, Kim MJ, Furia B, Romfo C, Graci JD, Li W, et al. 2019. Targeting of hematologic malignancies with PTC299, a novel potent inhibitor of dihydroorotate dehydrogenase with favorable pharmaceutical properties. Mol Cancer Ther 18: 3-16. doi:10.1158/1535-7163.MCT-18-0863

Caro P, Kishan AU, Norberg E, Stanley IA, Chapuy B, Ficarro SB, Polak K, Tondera D, Gounarides J, Yin H, et al. 2012. Metabolic signatures uncover distinct targets in molecular subsets of diffuse large B cell lymphoma. Cancer Cell 22: 547-560. doi:10.1016/j.ccr.2012.08.014

Carracedo A, Cantley LC, Pandolfi PP. 2013. Cancer metabolism: Fatty acid oxidation in the limelight. Nat Rev Cancer 13: 227-232. doi:10.1038/nrc3483

Castillo JJ, Mull N, Reagan JL, Nemr S, Mitri J. 2012. Increased incidence of non-Hodgkin lymphoma, leukemia, and myeloma in patients with diabetes mellitus type 2: A meta-analysis of observational studies. Blood 119: 48454850. doi:10.1182/blood-2011-06-362830
Chan SM, Thomas D, Corces-Zimmerman MR, Xavy S, Rastogi S, Hong WJ, Zhao F, Medeiros BC, Tyvoll DA, Majeti R. 2015. Isocitrate dehydrogenase 1 and 2 mutations induce BCL-2 dependence in acute myeloid leukemia. Nat Med 21: 178-184. doi:10.1038/nm.3788

Chan LN, Chen Z, Braas D, Lee JW, Xiao G, Geng H, Cosgun KN, Hurtz C, Shojaee S, Cazzaniga V, et al. 2017. Metabolic gatekeeper function of B-lymphoid transcription factors. Nature 542: 479-483. doi:10.1038/nature21076

Chen WL, Wang JH, Zhao AH, Xu X, Wang YH, Chen TL, Li JM, Mi JQ, Zhu YM, Liu YF, et al. 2014. A distinct glucose metabolism signature of acute myeloid leukemia with prognostic value. Blood 124: 1645-1654. doi:10.1182/ blood-2014-02-554204

Chen WL, Wang YY, Zhao A, Xia L, Xie G, Su M, Zhao L, Liu J, Qu C, Wei R, et al. 2016. Enhanced fructose utilization mediated by SLC2A5 is a unique metabolic feature of acute myeloid leukemia with therapeutic potential. Cancer Cell 30: 779-791. doi:10.1016/j.ccell.2016.09.006

Chen CC, Li B, Millman SE, Chen C, Li X, Morris J, Mayle A, Ho YJ, Loizou E, Liu H, et al. 2020. Vitamin B6 addiction in acute myeloid leukemia. Cancer Cell 37: 71-84.e7. doi:10.1016/j.ccell.2019.12.002

Chiche J, Pommier S, Beneteau M, Mondragon L, Meynet O, Zunino B, Mouchotte A, Verhoeyen E, Guyot M, Pagès G, et al. 2015. GAPDH enhances the aggressiveness and the vascularization of non-Hodgkin's B lymphomas via NF$\kappa B$-dependent induction of HIF-1 1 . Leukemia 29: 11631176. doi:10.1038/leu.2014.324

Chiche J, Reverso-Meinietti J, Mouchotte A, Rubio-Patiño C, Mhaidly R, Villa E, Bossowski JP, Proics E, GrimaReyes M, Paquet A, et al. 2019. GAPDH expression predicts the response to $\mathrm{R}-\mathrm{CHOP}$, the tumor metabolic status, and the response of DLBCL patients to metabolic inhibitors. Cell Metab 29: 1243-1257.e10. doi:10.1016/j .cmet.2019.02.002

Chien WW, Le Beux C, Rachinel N, Julien M, Lacroix CE, Allas S, Sahakian P, Cornut-Thibaut A, Lionnard L, Kucharczak J, et al. 2015. Differential mechanisms of asparaginase resistance in B-type acute lymphoblastic leukemia and malignant natural killer cell lines. Sci Rep 5: 8068. doi:10.1038/srep08068

Christian S, Merz C, Evans L, Gradl S, Seidel H, Friberg A, Eheim A, Lejeune P, Brzezinka K, Zimmermann K, et al. 2019. The novel dihydroorotate dehydrogenase (DHODH) inhibitor BAY 2402234 triggers differentiation and is effective in the treatment of myeloid malignancies. Leukemia 33: 2403-2415. doi:10.1038/s41375019-0461-5

Chukkapalli V, Gordon LI, Venugopal P, Borgia JA, Karmali R. 2018. Metabolic changes associated with metformin potentiates Bcl-2 inhibitor, Venetoclax, and CDK9 inhibitor, BAY1143572 and reduces viability of lymphoma cells. Oncotarget 9: 21166-21181. doi:10.18632/oncotar get.24989

Cimmino L, Dolgalev I, Wang Y, Yoshimi A, Martin GH, Wang J, Ng V, Xia B, Witkowski MT, Mitchell-Flack M, et al. 2017. Restoration of TET2 function blocks aberrant self-renewal and leukemia progression. Cell 170: 10791095.e20. doi:10.1016/j.cell.2017.07.032 
Cimmino L, Neel BG, Aifantis I. 2018. Vitamin C in stem cell reprogramming and cancer. Trends Cell Biol 28: 698-708. doi:10.1016/j.tcb.2018.04.001

Clavell LA, Gelber RD, Cohen HJ, Hitchcock-Bryan S, Cassady JR, Tarbell NJ, Blattner SR, Tantravahi R, Leavitt P, Sallan SE. 1986. Four-agent induction and intensive asparaginase therapy for treatment of childhood acute lymphoblastic leukemia. $N$ Engl J Med 315: 657-663. doi:10 .1056/NEJM198609113151101

Clutterbuck RD, Millar BC, Powles RL, Newman A, Catovsky D, Jarman M, Millar JL. 1998. Inhibitory effect of simvastatin on the proliferation of human myeloid leukaemia cells in severe combined immunodeficient (SCID) mice. Br J Haematol 102: 522-527. doi:10.1046/j.13652141.1998.00783.x

Cole A, Wang Z, Coyaud E, Voisin V, Gronda M, Jitkova Y, Mattson R, Hurren R, Babovic S, Maclean N, et al. 2015. Inhibition of the mitochondrial protease $\mathrm{ClpP}$ as a therapeutic strategy for human acute myeloid leukemia. Cancer Cell 27: 864-876. doi:10.1016/j.ccell.2015.05.004

Colegio OR, Chu NQ, Szabo AL, Chu T, Rhebergen AM, Jairam V, Cyrus N, Brokowski CE, Eisenbarth SC, Phillips GM, et al. 2014. Functional polarization of tumour-associated macrophages by tumour-derived lactic acid. Nature 513: 559-563. doi:10.1038/nature 13490

Coloff JL, Macintyre AN, Nichols AG, Liu T, Gallo CA, Plas DR, Rathmell JC. 2011. Akt-dependent glucose metabolism promotes Mcl-1 synthesis to maintain cell survival and resistance to Bcl-2 inhibition. Cancer Res 71: 52045213. doi:10.1158/0008-5472.CAN-10-4531

Cramer SL, Saha A, Liu J, Tadi S, Tiziani S, Yan W, Triplett K, Lamb C, Alters SE, Rowlinson S, et al. 2017. Systemic depletion of L-cyst(e)ine with cyst(e)inase increases reactive oxygen species and suppresses tumor growth. Nat Med 23: 120-127. doi:10.1038/nm.4232

Currie E, Schulze A, Zechner R, Walther TC, Farese RV Jr. 2013. Cellular fatty acid metabolism and cancer. Cell Metab 18: 153-161. doi:10.1016/j.cmet.2013.05.017

d'Amore F, Gaulard P, Trümper L, Corradini P, Kim WS, Specht L, Bjerregaard Pedersen M, Ladetto M, ESMO Guidelines Committee. 2015. Peripheral T-cell lymphomas: ESMO Clinical Practice Guidelines for diagnosis, treatment and follow-up. Ann Oncol 26: v108-v115. doi:10.1093/annonc/mdv201

Dang L, White DW, Gross S, Bennett BD, Bittinger MA, Driggers EM, Fantin VR, Jang HG, Jin S, Keenan MC, et al. 2009. Cancer-associated IDH1 mutations produce 2-hydroxyglutarate. Nature 462: 739-744. doi:10.1038/ nature 08617

Dieck CL, Tzoneva G, Forouhar F, Carpenter Z, AmbesiImpiombato A, Sánchez-Martín M, Kirschner-Schwabe R, Lew S, Seetharaman J, Tong L, et al. 2018. Structure and mechanisms of NT5C2 mutations driving thiopurine resistance in relapsed lymphoblastic leukemia. Cancer Cell 34: 136-147.e6. doi:10.1016/j.ccell.2018.06.003

Diehl FF, Lewis CA, Fiske BP, Vander Heiden MG. 2019. Cellular redox state constrains serine synthesis and nucleotide production to impact cell proliferation. Nat Metab 1: 861-867. doi:10.1038/s42255-019-0108-x

Dimitroulakos J, Thai S, Wasfy GH, Hedley DW, Minden MD, Penn LZ. 2000. Lovastatin induces a pronounced differentiation response in acute myeloid leukemias.
Metabolic Hallmarks of Leukemia and Lymphoma

Leuk Lymphoma 40: 167-178. doi:10.3109/10428190 009054894

DiNardo CD, Stein EM, de Botton S, Roboz GJ, Altman JK, Mims AS, Swords R, Collins RH, Mannis GN, Pollyea D, et al. 2018. Durable remissions with Ivosidenib in IDH1mutated relapsed or refractory AML. N Engl J Med 378: 2386-2398. doi:10.1056/NEJMoa1716984

DiNardo CD, Pratz K, Pullarkat V, Jonas BA, Arellano M, Becker PS, Frankfurt O, Konopleva M, Wei AH, Kantarjian $\mathrm{H}$, et al. 2019. Venetoclax combined with decitabine or azacitidine in treatment-naive, elderly patients with acute myeloid leukemia. Blood 133: 7-17. doi:10 .1182/blood-2018-08-868752

Ducker GS, Ghergurovich JM, Mainolfi N, Suri V, Jeong SK, Hsin-Jung Li S, Friedman A, Manfredi MG, Gitai Z, Kim $\mathrm{H}$, et al. 2017. Human SHMT inhibitors reveal defective glycine import as a targetable metabolic vulnerability of diffuse large B-cell lymphoma. Proc Natl Acad Sci 114: 11404-11409. doi:10.1073/pnas.1706617114

Eberlin LS, Gabay M, Fan AC, Gouw AM, Tibshirani RJ, Felsher DW, Zare RN. 2014. Alteration of the lipid profile in lymphomas induced by MYC overexpression. Proc Natl Acad Sci 111: 10450-10455. doi:10.1073/pnas .1409778111

Ehsanipour EA, Sheng X, Behan JW, Wang X, Butturini A, Avramis VI, Mittelman SD. 2013. Adipocytes cause leukemia cell resistance to L-asparaginase via release of glutamine. Cancer Res 73: 2998-3006. doi:10.1158/00085472.CAN-12-4402

Eil R, Vodnala SK, Clever D, Klebanoff CA, Sukumar M, Pan JH, Palmer DC, Gros A, Yamamoto TN, Patel SJ, et al. 2016. Ionic immune suppression within the tumour microenvironment limits T cell effector function. Nature 537: 539-543. doi:10.1038/nature19364

Elkashef SM, Lin AP, Myers J, Sill H, Jiang D, Dahia PLM, Aguiar RCT. 2017. IDH mutation, competitive inhibition of FTO, and RNA methylation. Cancer Cell 31: 619-620. doi:10.1016/j.ccell.2017.04.001

Emadi A. 2015. Exploiting AML vulnerability: Glutamine dependency. Blood 126: 1269-1270. doi:10.1182/blood2015-07-659508

Fan J, Ye J, Kamphorst JJ, Shlomi T, Thompson CB, Rabinowitz JD. 2014. Quantitative flux analysis reveals folatedependent NADPH production. Nature 510: 298-302. doi:10.1038/nature13236

Farber S, Diamond LK. 1948. Temporary remissions in acute leukemia in children produced by folic acid antagonist, 4aminopteroyl-glutamic acid (Aminopterin). NEngl J Med 238: 787-793. doi:10.1056/NEJM194806032382301

Farge T, Saland E, de Toni F, Aroua N, Hosseini M, Perry R, Bosc C, Sugita M, Stuani L, Fraisse M, et al. 2017. Chemotherapy-resistant human acute myeloid leukemia cells are not enriched for leukemic stem cells but require oxidative metabolism. Cancer Discov 7: 716-735. doi:10 .1158/2159-8290.CD-16-0441

Faubert B, Boily G, Izreig S, Griss T, Samborska B, Dong Z, Dupuy F, Chambers C, Fuerth BJ, Viollet B, et al. 2013. AMPK is a negative regulator of the Warburg effect and suppresses tumor growth in vivo. Cell Metab 17: 113-124. doi:10.1016/j.cmet.2012.12.001

Feinberg AP, Koldobskiy MA, Göndör A. 2016. Epigenetic modulators, modifiers and mediators in cancer aetiology 
M. Stahl et al.

and progression. Nat Rev Genet 17: 284-299. doi:10.1038/ nrg.2016.13

Fenouille N, Bassil CF, Ben-Sahra I, Benajiba L, Alexe G, Ramos A, Pikman Y, Conway AS, Burgess MR, Li Q, et al. 2017. The creatine kinase pathway is a metabolic vulnerability in EVI1-positive acute myeloid leukemia. Nat Med 23: 301-313. doi:10.1038/nm.4283

Figueroa ME, Abdel-Wahab O, Lu C, Ward PS, Patel J, Shih A, Li Y, Bhagwat N, Vasanthakumar A, Fernandez HF, et al. 2010. Leukemic IDH1 and IDH2 mutations result in a hypermethylation phenotype, disrupt TET2 function, and impair hematopoietic differentiation. Cancer Cell 18: 553-567. doi:10.1016/j.ccr.2010.11.015

Fu X, Chin RM, Vergnes L, Hwang H, Deng G, Xing Y, Pai MY, Li S, Ta L, Fazlollahi F, et al. 2015. 2-Hydroxyglutarate inhibits ATP synthase and mTOR signaling. Cell Metab 22: 508-515. doi:10.1016/j.cmet.2015.06.009

Gallipoli P, Giotopoulos G, Tzelepis K, Costa ASH, Vohra S, Medina-Perez P, Basheer F, Marando L, Di Lisio L, Dias JML, et al. 2018. Glutaminolysis is a metabolic dependency in FLT3 ${ }^{\text {ITD }}$ acute myeloid leukemia unmasked by FLT3 tyrosine kinase inhibition. Blood 131: 1639-1653. doi:10.1182/blood-2017-12-820035

Gao P, Tchernyshyov I, Chang TC, Lee YS, Kita K, Ochi T, Zeller KI, De Marzo AM, Van Eyk JE, Mendell JT, et al. 2009. c-Myc suppression of miR-23a/b enhances mitochondrial glutaminase expression and glutamine metabolism. Nature 458: 762-765. doi:10.1038/nature07823

Garcia-Bermudez J, Baudrier L, La K, Zhu XG, Fidelin J, Sviderskiy VO, Papagiannakopoulos T, Molina H, Snuderl M, Lewis CA, et al. 2018. Aspartate is a limiting metabolite for cancer cell proliferation under hypoxia and in tumours. Nat Cell Biol 20: 775-781. doi:10.1038/ s41556-018-0118-z

Garcia-Bermudez J, Baudrier L, Bayraktar EC, Shen Y, La K, Guarecuco R, Yucel B, Fiore D, Tavora B, Freinkman E, et al. 2019. Squalene accumulation in cholesterol auxotrophic lymphomas prevents oxidative cell death. Nature 567: 118-122. doi:10.1038/s41586-019-0945-5

German NJ, Yoon H, Yusuf RZ, Murphy JP, Finley LW, Laurent G, Haas W, Satterstrom FK, Guarnerio J, Zaganjor E, et al. 2016. PHD3 loss in cancer enables metabolic reliance on fatty acid oxidation via deactivation of ACC2. Mol Cell 63: 1006-1020. doi:10.1016/j.molcel.2016.08 .014

Goncalves MD, Lu C, Tutnauer J, Hartman TE, Hwang SK, Murphy CJ, Pauli C, Morris R, Taylor S, Bosch K, et al. 2019. High-fructose corn syrup enhances intestinal tumor growth in mice. Science 363: 1345-1349. doi:10 $.1126 /$ science.aat 8515

Gottschalk S, Anderson N, Hainz C, Eckhardt SG, Serkova NJ. 2004. Imatinib (STI571)-mediated changes in glucose metabolism in human leukemia BCR-ABL-positive cells. Clin Cancer Res 10: 6661-6668. doi:10.1158/1078-0432 CCR-04-0039

Gouw AM, Margulis K, Liu NS, Raman SJ, Mancuso A, Toal GG, Tong L, Mosley A, Hsieh AL, Sullivan DK, et al. 2019. The MYC oncogene cooperates with sterol-regulated element-binding protein to regulate lipogenesis essential for neoplastic growth. Cell Metab 30: 556-572.e5. doi:10 $.1016 /$ j.cmet.2019.07.012
Gregory MA, Nemkov T, Reisz JA, Zaberezhnyy V, Hansen KC, D'Alessandro A, DeGregori J. 2018. Glutaminase inhibition improves FLT3 inhibitor therapy for acute myeloid leukemia. Exp Hematol 58: 52-58. doi:10.1016/j .exphem.2017.09.007

Gregory MA, Nemkov T, Park HJ, Zaberezhnyy V, Gehrke S, Adane B, Jordan CT, Hansen KC, D'Alessandro A, DeGregori J. 2019. Targeting glutamine metabolism and redox state for leukemia therapy. Clin Cancer Res 25: 4079-4090. doi:10.1158/1078-0432.CCR-18-3223

Gu JJ, Singh A, Xue K, Mavis C, Barth M, Yanamadala V, Lenz P, Grau M, Lenz G, Czuczman MS, et al. 2018. Upregulation of hexokinase II contributes to rituximab-chemotherapy resistance and is a clinically relevant target for therapeutic development. Oncotarget 9: 4020-4033. doi:10.18632/oncotarget.23425

Guièze R, Liu VM, Rosebrock D, Jourdain AA, HernándezSánchez M, Martinez Zurita A, Sun J, Ten Hacken E, Baranowski K, Thompson PA, et al. 2019. Mitochondrial reprogramming underlies resistance to BCL-2 inhibition in lymphoid malignancies. Cancer Cell 36: 369-384.e13. doi:10.1016/j.ccell.2019.08.005

Hattori A, Tsunoda M, Konuma T, Kobayashi M, Nagy T, Glushka J, Tayyari F, McSkimming D, Kannan N, Tojo A, et al. 2017. Cancer progression by reprogrammed BCAA metabolism in myeloid leukaemia. Nature 545: 500-504. doi:10.1038/nature22314

Hensley CT, Faubert B, Yuan Q, Lev-Cohain N, Jin E, Kim J, Jiang L, Ko B, Skelton R, Loudat L, et al. 2016. Metabolic heterogeneity in human lung tumors. Cell 164: 681-694. doi:10.1016/j.cell.2015.12.034

Herranz D, Ambesi-Impiombato A, Sudderth J, SanchezMartin M, Belver L, Tosello V, Xu L, Wendorff AA, Castillo M, Haydu JE, et al. 2015. Metabolic reprogramming induces resistance to anti-NOTCH1 therapies in T cell acute lymphoblastic leukemia. Nat Med 21: 1182-1189. doi:10.1038/nm.3955

Herst PM, Howman RA, Neeson PJ, Berridge MV, Ritchie DS. 2011. The level of glycolytic metabolism in acute myeloid leukemia blasts at diagnosis is prognostic for clinical outcome. J Leukoc Biol 89: 51-55. doi:10.1189/ jlb.0710417

Holleman A, Cheok MH, den Boer ML, Yang W, Veerman AJ, Kazemier KM, Pei D, Cheng C, Pui CH, Relling MV, et al. 2004. Gene-expression patterns in drug-resistant acute lymphoblastic leukemia cells and response to treatment. N Engl J Med 351: 533-542. doi:10.1056/NEJMoa033513

Hopkins BD, Pauli C, Du X, Wang DG, Li X, Wu D, Amadiume SC, Goncalves MD, Hodakoski C, Lundquist MR, et al. 2018. Suppression of insulin feedback enhances the efficacy of PI3 K inhibitors. Nature 560: 499-503. doi:10 .1038/s41586-018-0343-4

Hosios AM, Vander Heiden MG. 2018. The redox requirements of proliferating mammalian cells. J Biol Chem 293: 7490-7498. doi:10.1074/jbc.TM117.000239

Hosios AM, Hecht VC, Danai LV, Johnson MO, Rathmell JC, Steinhauser ML, Manalis SR, Vander Heiden MG. 2016. Amino acids rather than glucose account for the majority of cell mass in proliferating mammalian cells. Dev Cell 36: 540-549. doi:10.1016/j.devcel.2016.02.012

Hui S, Ghergurovich JM, Morscher RJ, Jang C, Teng X, Lu W, Esparza LA, Reya T, Le Z, Yanxiang Guo J, et al. 2017. 
Glucose feeds the TCA cycle via circulating lactate. Nature 551: 115-118. doi:10.1038/nature24057

Huijskens MJ, Wodzig WK, Walczak M, Germeraad WT, Bos GM. 2016. Ascorbic acid serum levels are reduced in patients with hematological malignancies. Results Immunol 6: 8-10. doi:10.1016/j.rinim.2016.01.001

Hulleman E, Kazemier KM, Holleman A, VanderWeele DJ, Rudin CM, Broekhuis MJ, Evans WE, Pieters R, Den Boer ML. 2009. Inhibition of glycolysis modulates prednisolone resistance in acute lymphoblastic leukemia cells. Blood 113: 2014-2021. doi:10.1182/blood-200805-157842

Intlekofer AM, Finley LWS. 2019. Metabolic signatures of cancer cells and stem cells. Nat Metab 1: 177-188. doi:10 .1038/s42255-019-0032-0

Jacque N, Ronchetti AM, Larrue C, Meunier G, Birsen R, Willems L, Saland E, Decroocq J, Maciel TT, Lambert M, et al. 2015. Targeting glutaminolysis has antileukemic activity in acute myeloid leukemia and synergizes with BCL-2 inhibition. Blood 126: 1346-1356. doi:10.1182/ blood-2015-01-621870

Jiang P, Du W, Wang X, Mancuso A, Gao X, Wu M, Yang X. 2011. p53 regulates biosynthesis through direct inactivation of glucose-6-phosphate dehydrogenase. Nat Cell Biol 13: 310-316. doi:10.1038/ncb2172

Jiang P, Du W, Mancuso A, Wellen KE, Yang X. 2013. Reciprocal regulation of p53 and malic enzymes modulates metabolism and senescence. Nature 493: 689-693. doi:10 1038/nature11776

Jones CL, Stevens BM, D’Alessandro A, Reisz JA, Culp-Hill R, Nemkov T, Pei S, Khan N, Adane B, Ye H, et al. 2018 Inhibition of amino acid metabolism selectively targets human leukemia stem cells. Cancer Cell 34: 724-740.e4 doi:10.1016/j.ccell.2018.10.005

Jones CL, Stevens BM, D’Alessandro A, Culp-Hill R, Reisz JA, Pei S, Gustafson A, Khan N, DeGregori J, Pollyea DA et al. 2019. Cysteine depletion targets leukemia stem cells through inhibition of electron transport complex II. Blood 134: 389-394. doi:10.1182/blood.2019898114

Ju HQ, Zhan G, Huang A, Sun Y, Wen S, Yang J, Lu WH, Xu RH, Li J, Li Y, et al. 2017. ITD mutation in FLT3 tyrosine kinase promotes Warburg effect and renders therapeutic sensitivity to glycolytic inhibition. Leukemia 31 : 21432150. doi:10.1038/leu.2017.45

Khan H, Anshu A, Prasad A, Roy S, Jeffery J, Kittipongdaja W, Yang DT, Schieke SM. 2019. Metabolic rewiring in response to biguanides is mediated by mROS/HIF-1a in malignant lymphocytes. Cell Rep 29: 3009-3018.e4. doi:10.1016/j.celrep.2019.11.007

Khanim FL, Hayden RE, Birtwistle J, Lodi A, Tiziani S, Davies NJ, Ride JP, Viant MR, Gunther UL, Mountford JC, et al. 2009. Combined bezafibrate and medroxyprogesterone acetate: Potential novel therapy for acute myeloid leukaemia. PLoS One 4: e8147. doi:10.1371/journal .pone. 0008147

Kimmelman AC. 2015. Metabolic dependencies in RASdriven cancers. Clin Cancer Res 21: 1828-1834. doi:10 .1158/1078-0432.CCR-14-2425

Kinnaird A, Zhao S, Wellen KE, Michelakis ED. 2016. Metabolic control of epigenetics in cancer. Nat Rev Cancer 16: 694-707. doi:10.1038/nrc.2016.82
Koivunen P, Lee S, Duncan CG, Lopez G, Lu G, Ramkissoon S, Losman JA, Joensuu P, Bergmann U, Gross S, et al. 2012. Transformation by the $(R)$-enantiomer of 2-hydroxyglutarate linked to EGLN activation. Nature 483: 484-488. doi:10.1038/nature10898

Kornblau SM, Banker DE, Stirewalt D, Shen D, Lemker E, Verstovsek S, Estrov Z, Faderl S, Cortes J, Beran M, et al. 2007. Blockade of adaptive defensive changes in cholesterol uptake and synthesis in AML by the addition of pravastatin to idarubicin + high-dose Ara-C: A phase 1 study. Blood 109: 2999-3006. doi:10.1182/blood-200608-044446

Kuntz EM, Baquero P, Michie AM, Dunn K, Tardito S, Holyoake TL, Helgason GV, Gottlieb E. 2017. Targeting mitochondrial oxidative phosphorylation eradicates therapy-resistant chronic myeloid leukemia stem cells. Nat Med 23: 1234-1240. doi:10.1038/nm.4399

Ladds M, van Leeuwen IMM, Drummond CJ, Chu S, Healy AR, Popova G, Pastor Fernández A, Mollick T, Darekar S, Sedimbi SK, et al. 2018. A DHODH inhibitor increases p53 synthesis and enhances tumor cell killing by p53 degradation blockage. Nat Commun 9: 1107. doi:10 .1038/s41467-018-03441-3

Lagadinou ED, Sach A, Callahan K, Rossi RM, Neering SJ, Minhajuddin M, Ashton JM, Pei S, Grose V, O’Dwyer KM, et al. 2013. BCL-2 inhibition targets oxidative phosphorylation and selectively eradicates quiescent human leukemia stem cells. Cell Stem Cell 12: 329-341. doi:10 .1016/j.stem.2012.12.013

Larrue C, Saland E, Vergez F, Serhan N, Delabesse E, Mansat-De Mas V, Hospital MA, Tamburini J, Manenti S, Sarry JE, et al. 2015. Antileukemic activity of 2-deoxy$d$-glucose through inhibition of N-linked glycosylation in acute myeloid leukemia with FLT3-ITD or c-KIT mutations. Mol Cancer Ther 14: 2364-2373. doi:10.1158/ 1535-7163.MCT-15-0163

Le A, Lane AN, Hamaker M, Bose S, Gouw A, Barbi J, Tsukamoto T, Rojas CJ, Slusher BS, Zhang H, et al. 2012 Glucose-independent glutamine metabolism via TCA cycling for proliferation and survival in B cells. Cell Metab 15: 110-121. doi:10.1016/j.cmet.2011.12.009

Lee JS, Roberts A, Juarez D, Vo TT, Bhatt S, Herzog LO, Mallya S, Bellin RJ, Agarwal SK, Salem AH, et al. 2018. Statins enhance efficacy of venetoclax in blood cancers. Sci Transl Med 10: eaaq1240.

Lee SC, Shestov AA, Guo L, Zhang Q, Roman JC, Liu X, Wang HY, Pickup S, Nath K, Lu P, et al. 2019. Metabolic detection of Bruton's tyrosine kinase inhibition in mantle cell lymphoma cells. Mol Cancer Res 17: 1365-1377.

Lemonnier F, Cairns RA, Inoue S, Li WY, Dupuy A, Broutin S, Martin N, Fataccioli V, Pelletier R, Wakeham A, et al. 2016. The IDH2 R172 K mutation associated with angioimmunoblastic T-cell lymphoma produces $2 \mathrm{HG}$ in $\mathrm{T}$ cells and impacts lymphoid development. Proc Natl Acad Sci 113: 15084-15089. doi:10.1073/pnas.1617929114

Li M, Chiang YL, Lyssiotis CA, Teater MR, Hong JY, Shen H, Wang L, Hu J, Jing H, Chen Z, et al. 2019. Non-oncogene addiction to SIRT3 plays a critical role in lymphomagenesis. Cancer Cell 35: 916-931.e9. doi:10.1016/j.ccell.2019 .05 .002

Lin AP, Abbas S, Kim SW, Ortega M, Bouamar H, Escobedo Y, Varadarajan P, Qin Y, Sudderth J, Schulz E, et al. 2015. 
M. Stahl et al.

D2HGDH regulates alpha-ketoglutarate levels and dioxygenase function by modulating IDH2. Nat Commun $\mathbf{6}$ : 7768. doi:10.1038/ncomms8768

Lin KH, Xie A, Rutter JC, Ahn YR, Lloyd-Cowden JM, Nichols AG, Soderquist RS, Koves TR, Muoio DM, MacIver NJ, et al. 2019. Systematic dissection of the metabolicapoptotic interface in AML reveals heme biosynthesis to be a regulator of drug sensitivity. Cell Metab 29: 12171231.e7. doi:10.1016/j.cmet.2019.01.011

Liu T, Kishton RJ, Macintyre AN, Gerriets VA, Xiang H, Liu X, Abel ED, Rizzieri D, Locasale JW, Rathmell JC. 2014 Glucose transporter 1-mediated glucose uptake is limiting for B-cell acute lymphoblastic leukemia anabolic metabolism and resistance to apoptosis. Cell Death Dis 5: e1470. doi:10.1038/cddis.2014.431

Liyanage SU, Hurren R, Voisin V, Bridon G, Wang X, Xu C, MacLean N, Siriwardena TP, Gronda M, Yehudai D, et al. 2017. Leveraging increased cytoplasmic nucleoside kinase activity to target mtDNA and oxidative phosphorylation in AML. Blood 129: 2657-2666. doi:10.1182/blood-201610-741207

Locasale JW. 2013. Serine, glycine and one-carbon units: Cancer metabolism in full circle. Nat Rev Cancer 13: 572-583. doi:10.1038/nrc3557

Losman JA, Kaelin WG Jr. 2013. What a difference a hydroxyl makes: Mutant IDH, $(R)$-2-hydroxyglutarate, and cancer. Genes Dev 27: 836-852. doi:10.1101/gad.217406 .113

Lu C, Ward PS, Kapoor GS, Rohle D, Turcan S, Abdel-Wahab O, Edwards CR, Khanin R, Figueroa ME, Melnick A et al. 2012. IDH mutation impairs histone demethylation and results in a block to cell differentiation. Nature 483: 474-478. doi:10.1038/nature10860

Lu Z, Xie J, Wu G, Shen J, Collins R, Chen W, Kang X, Luo M, Zou Y, Huang LJ, et al. 2017. Fasting selectively blocks development of acute lymphoblastic leukemia via leptinreceptor upregulation. Nat Med 23: 79-90. doi:10.1038/ nm. 4252

Mardis ER, Ding L, Dooling DJ, Larson DE, McLellan MD, Chen K, Koboldt DC, Fulton RS, Delehaunty KD, McGrath SD, et al. 2009. Recurring mutations found by sequencing an acute myeloid leukemia genome. $N$ Engl $J$ Med 361: 1058-1066. doi:10.1056/NEJMoa0903840

Martín-Lorenzo A, Auer F, Chan LN, García-Ramírez I, González-Herrero I, Rodríguez-Hernández G, Bartenhagen C, Dugas M, Gombert M, Ginzel S, et al. 2018. Loss of Pax 5 exploits Sca1-BCR-ABL ${ }^{\mathrm{p} 190}$ susceptibility to confer the metabolic shift essential for pB-ALL. Cancer Res 78: 2669-2679. doi:10.1158/0008-5472.CAN-17-3262

Matre P, Velez J, Jacamo R, Qi Y, Su X, Cai T, Chan SM, Lodi A, Sweeney SR, Ma H, et al. 2016. Inhibiting glutaminase in acute myeloid leukemia: Metabolic dependency of selected AML subtypes. Oncotarget 7: 79722-79735. doi:10 $.18632 /$ oncotarget.12944

McBrayer SK, Mayers JR, DiNatale GJ, Shi DD, Khanal J, Chakraborty AA, Sarosiek KA, Briggs KJ, Robbins AK, Sewastianik T, et al. 2018. Transaminase inhibition by 2hydroxyglutarate impairs glutamate biosynthesis and redox homeostasis in glioma. Cell 175: 101-116.e25. doi:10 .1016/j.cell.2018.08.038

McFadden K, Hafez AY, Kishton R, Messinger JE, Nikitin PA, Rathmell JC, Luftig MA. 2016. Metabolic stress is a barrier to Epstein-Barr virus-mediated B-cell immortalization. Proc Natl Acad Sci 113: E782-E790. doi:10.1073/ pnas. 1517141113

Meyer JA, Wang J, Hogan LE, Yang JJ, Dandekar S, Patel JP, Tang Z, Zumbo P, Li S, Zavadil J, et al. 2013. Relapse-specific mutations in NT5C2 in childhood acute lymphoblastic leukemia. Nat Genet 45: 290-294. doi:10 .1038/ng.2558

Michelozzi IM, Granata V, De Ponti G, Alberti G, Tomasoni C, Antolini L, Gambacorti-Passerini C, Gentner B, Dazzi F, Biondi A, et al. 2019. Acute myeloid leukaemia niche regulates response to L-asparaginase. $\mathrm{Br} J$ Haematol 186: 420-430.

Miraki-Moud F, Ghazaly E, Ariza-McNaughton L, Hodby KA, Clear A, Anjos-Afonso F, Liapis K, Grantham M, Sohrabi F, Cavenagh J, et al. 2015. Arginine deprivation using pegylated arginine deiminase has activity against primary acute myeloid leukemia cells in vivo. Blood 125: 4060-4068. doi:10.1182/blood-2014-10-608133

Mitri J, Castillo J, Pittas AG. 2008. Diabetes and risk of Non-Hodgkin's lymphoma: A meta-analysis of observational studies. Diabetes Care 31: 2391-2397. doi:10.2337/ dc08-1034

Moertel CG, Fleming TR, Creagan ET, Rubin J, O’Connell MJ, Ames MM. 1985. High-dose vitamin C versus placebo in the treatment of patients with advanced cancer who have had no prior chemotherapy. A randomized doubleblind comparison. N Engl J Med 312: 137-141. doi:10 .1056/NEJM198501173120301

Molina JR, Sun Y, Protopopova M, Gera S, Bandi M, Bristow C, McAfoos T, Morlacchi P, Ackroyd J, Agip AA, et al. 2018. An inhibitor of oxidative phosphorylation exploits cancer vulnerability. Nat Med 24: 1036-1046. doi:10 .1038/s41591-018-0052-4

Monti S, Savage KJ, Kutok JL, Feuerhake F, Kurtin P, Mihm M, Wu B, Pasqualucci L, Neuberg D, Aguiar RC, et al. 2005. Molecular profiling of diffuse large B-cell lymphoma identifies robust subtypes including one characterized by host inflammatory response. Blood 105: 1851-1861. doi:10.1182/blood-2004-07-2947

Montrose DC, Galluzzi L. 2019. Drugging cancer metabolism: Expectations vs. reality. Int Rev Cell Mol Biol 347: 126. doi:10.1016/bs.ircmb.2019.07.007

Morrish F, Noonan J, Perez-Olsen C, Gafken PR, Fitzgibbon M, Kelleher J, VanGilst M, Hockenbery D. 2010. Mycdependent mitochondrial generation of acetyl-CoA contributes to fatty acid biosynthesis and histone acetylation during cell cycle entry. J Biol Chem 285: 36267-36274. doi:10.1074/jbc.M110.141606

Mullighan CG, Goorha S, Radtke I, Miller CB, CoustanSmith E, Dalton JD, Girtman K, Mathew S, Ma J, Pounds SB, et al. 2007. Genome-wide analysis of genetic alterations in acute lymphoblastic leukaemia. Nature 446: 758-764. doi:10.1038/nature05690

Mullighan CG, Miller CB, Radtke I, Phillips LA, Dalton J, Ma J, White D, Hughes TP, Le Beau MM, Pui CH, et al. 2008. $B C R-A B L 1$ lymphoblastic leukaemia is characterized by the deletion of Ikaros. Nature 453: 110-114 doi:10.1038/nature06866

Murray JA, Khanim FL, Hayden RE, Craddock CF, Holyoake TL, Jackson N, Lumley M, Bunce CM, Drayson MT. 2010. Combined bezafibrate and medroxyprogesterone acetate 
have efficacy without haematological toxicity in elderly and relapsed acute myeloid leukaemia (AML). Br J Haematol 149: 65-69. doi:10.1111/j.1365-2141.2009.08055.x

Müschen M. 2019. Metabolic gatekeepers to safeguard against autoimmunity and oncogenic B cell transformation. Nat Rev Immunol 19: 337-348. doi:10.1038/s41577019-0154-3

Mussai F, De Santo C, Abu-Dayyeh I, Booth S, Quek L, McEwen-Smith RM, Qureshi A, Dazzi F, Vyas P, Cerundolo V. 2013. Acute myeloid leukemia creates an arginase-dependent immunosuppressive microenvironment Blood 122: 749-758. doi:10.1182/blood-2013-01-480129

Mussai F, Egan S, Higginbotham-Jones J, Perry T, Beggs A, Odintsova E, Loke J, Pratt G, U KP, Lo A, et al. 2015. Arginine dependence of acute myeloid leukemia blast proliferation: A novel therapeutic target. Blood 125: 2386-2396. doi:10.1182/blood-2014-09-600643

Nakajima K, Kawashima I, Koshiisi M, Kumagai T, Suzuki M, Suzuki J, Mitsumori T, Kirito K. 2019. Glycolytic enzyme hexokinase II is a putative therapeutic target in Bcell malignant lymphoma. Exp Hematol 78: 46-55.e3. doi:10.1016/j.exphem.2019.09.023

Newman A, Clutterbuck RD, Powles RL, Millar JL. 1994. Selective inhibition of primary acute myeloid leukaemia cell growth by simvastatin. Leukemia 8: 2023-2029.

Ni F, Yu WM, Li Z, Graham DK, Jin L, Kang S, Rossi MR, Li S, Broxmeyer HE, Qu CK. 2019. Critical role of ASCT2mediated amino acid metabolism in promoting leukaemia development and progression. Nat Metab 1: 390-403. doi:10.1038/s42255-019-0039-6

Norberg E, Lako A, Chen PH, Stanley IA, Zhou F, Ficarro SB, Chapuy B, Chen L, Rodig S, Shin D, et al. 2017. Differential contribution of the mitochondrial translation pathway to the survival of diffuse large B-cell lymphoma subsets. Cell Death Differ 24: 251-262. doi:10.1038/cdd .2016 .116

Noy A, Schöder H, Gönen M, Weissler M, Ertelt K, Cohler C, Portlock C, Hamlin P, Yeung HW. 2009. The majority of transformed lymphomas have high standardized uptake values (SUVs) on positron emission tomography (PET) scanning similar to diffuse large B-cell lymphoma (DLBCL). Ann Oncol 20: 508-512. doi:10.1093/annonc/ mdn657

Okosun J, Wolfson RL, Wang J, Araf S, Wilkins L, Castellano BM, Escudero-Ibarz L, Al Seraihi AF, Richter J, Bernhart $\mathrm{SH}$, et al. 2016. Recurrent mTORC1-activating RRAGC mutations in follicular lymphoma. Nat Genet 48: 183188. doi: $10.1038 /$ ng. 3473

Oricchio E, Katanayeva N, Donaldson MC, Sungalee S, Pasion JP, Béguelin W, Battistello E, Sanghvi VR, Jiang M, Jiang Y. 2017. Genetic and epigenetic inactivation of SESTRIN1 controls mTORC1 and response to EZH2 inhibition in follicular lymphoma. 9: eaak9969.

Ortega-Molina A, Deleyto-Seldas N, Carreras J, Sanz A, Lebrero-Fernández $\mathrm{C}$, Menéndez $\mathrm{C}$, Vandenberg $\mathrm{A}$, Fernández-Ruiz B, Marín-Arraiza L, de la Calle Arregui C, et al. 2019. Oncogenic Rag GTPase signalling enhances B cell activation and drives follicular lymphoma sensitive to pharmacological inhibition of mTOR. Nat Metab 1: 775-789. doi:10.1038/s42255-019-0098-8

Osthus RC, Shim H, Kim S, Li Q, Reddy R, Mukherjee M, Xu Y, Wonsey D, Lee LA, Dang CV. 2000. Deregulation of glucose transporter 1 and glycolytic gene expression by c-Myc. J Biol Chem 275: 21797-21800. doi:10.1074/jbc .C000023200

Palm W, Thompson CB. 2017. Nutrient acquisition strategies of mammalian cells. Nature 546: 234-242. doi:10 $.1038 /$ nature22379

Pardee TS, Lee K, Luddy J, Maturo C, Rodriguez R, Isom S, Miller LD, Stadelman KM, Levitan D, Hurd D, et al. 2014. A phase I study of the first-in-class antimitochondrial metabolism agent, CPI-613, in patients with advanced hematologic malignancies. Clin Cancer Res 20: 52555264. doi:10.1158/1078-0432.CCR-14-1019

Pardee TS, Anderson RG, Pladna KM, Isom S, Ghiraldeli LP, Miller LD, Chou JW, Jin G, Zhang W, Ellis LR, et al. 2018. A Phase I Study of CPI-613 in combination with high-dose cytarabine and mitoxantrone for relapsed or refractory acute myeloid leukemia. Clin Cancer Res 24: 2060-2073. doi:10.1158/1078-0432.CCR-17-2282

Parsa S, Ortega-Molina A, Ying HY, Jiang M, Teater M, Wang J, Zhao C, Reznik E, Pasion JP, Kuo D, et al. 2020. The serine hydroxymethyltransferase-2 (SHMT2) initiates lymphoma development through epigenetic tumor suppressor silencing. Nature Cancer 1: 653-664. doi:10.1038/s43018-020-0080-0

Pikman Y, Puissant A, Alexe G, Furman A, Chen LM, Frumm SM, Ross L, Fenouille N, Bassil CF, Lewis CA, et al. 2016. Targeting MTHFD2 in acute myeloid leukemia. J Exp Med 213: 1285-1306. doi:10.1084/jem .20151574

Pizer ES, Wood FD, Pasternack GR, Kuhajda FP. 1996. Fatty acid synthase (FAS): A target for cytotoxic antimetabolites in HL60 promyelocytic leukemia cells. Cancer Res 56: 745-751.

Pollyea DA, Stevens BM, Jones CL, Winters A, Pei S, Minhajuddin M, D'Alessandro A, Culp-Hill R, Riemondy KA, Gillen AE, et al. 2018. Venetoclax with azacitidine disrupts energy metabolism and targets leukemia stem cells in patients with acute myeloid leukemia. Nat Med 24: 1859-1866. doi:10.1038/s41591-018-0233-1

Poulain L, Sujobert P, Zylbersztejn F, Barreau S, Stuani L, Lambert M, Palama TL, Chesnais V, Birsen R, Vergez F, et al. 2017. High mTORC1 activity drives glycolysis addiction and sensitivity to G6PD inhibition in acute myeloid leukemia cells. Leukemia 31: 2326-2335. doi:10.1038/leu .2017 .81

Qing G, Li B, Vu A, Skuli N, Walton ZE, Liu X, Mayes PA, Wise DR, Thompson CB, Maris JM, et al. 2012. ATF4 regulates $M Y C$-mediated neuroblastoma cell death upon glutamine deprivation. Cancer Cell 22: 631-644. doi:10 $.1016 / j . c c r .2012 .09 .021$

Raffel S, Falcone M, Kneisel N, Hansson J, Wang W, Lutz C, Bullinger L, Poschet G, Nonnenmacher Y, Barnert A, et al. 2017. BCAT1 restricts $\alpha$ KG levels in AML stem cells leading to $\mathrm{IDH}^{\text {mut }}$-like DNA hypermethylation. Nature 551: 384-388. doi:10.1038/nature24294

Ricciardi MR, Mirabilii S, Allegretti M, Licchetta R, Calarco A, Torrisi MR, Foà R, Nicolai R, Peluso G, Tafuri A. 2015. Targeting the leukemia cell metabolism by the CPT1a inhibition: Functional preclinical effects in leukemias. Blood 126: 1925-1929. doi:10.1182/blood2014-12-617498 
M. Stahl et al.

Rohle D, Popovici-Muller J, Palaskas N, Turcan S, Grommes C, Campos C, Tsoi J, Clark O, Oldrini B, Komisopoulou E, et al. 2013. An inhibitor of mutant IDH1 delays growth and promotes differentiation of glioma cells. Science 340: 626-630. doi:10.1126/science.1236062

Samudio I, Harmancey R, Fiegl M, Kantarjian H, Konopleva M, Korchin B, Kaluarachchi K, Bornmann W, Duvvuri S, Taegtmeyer H, et al. 2010. Pharmacologic inhibition of fatty acid oxidation sensitizes human leukemia cells to apoptosis induction. J Clin Invest 120: 142-156. doi:10 $.1172 / J C I 38942$

Sanchez-Martin M, Ferrando A. 2017. The NOTCH1-MYC highway toward T-cell acute lymphoblastic leukemia Blood 129: 1124-1133. doi:10.1182/blood-2016-09692582

Saxton RA, Sabatini DM. 2017. mTOR signaling in growth, metabolism, and disease. Cell 168: 960-976. doi:10.1016/j cell.2017.02.004

Schuijers J, Manteiga JC, Weintraub AS, Day DS, Zamudio AV, Hnisz D, Lee TI, Young RA. 2018. Transcriptional dysregulation of MYC reveals common enhancer-docking mechanism. Cell Rep 23: 349-360. doi:10.1016/j celrep.2018.03.056

Scuoppo C, Miething C, Lindqvist L, Reyes J, Ruse C, Appelmann I, Yoon S, Krasnitz A, Teruya-Feldstein J, Pappin D, et al. 2012. A tumour suppressor network relying on the polyamine-hypusine axis. Nature 487: 244-248. doi:10.1038/nature11126

Seam P, Juweid ME, Cheson BD. 2007. The role of FDG-PET scans in patients with lymphoma. Blood 110: 3507-3516. doi:10.1182/blood-2007-06-097238

Sehn LH, Berry B, Chhanabhai M, Fitzgerald C, Gill K, Hoskins P, Klasa R, Savage KJ, Shenkier T, Sutherland J, et al. 2007. The revised International Prognostic Index (R-IPI) is a better predictor of outcome than the standard IPI for patients with diffuse large B-cell lymphoma treated with R-CHOP. Blood 109: 1857-1861. doi:10.1182/blood2006-08-038257

Shadman M, Mawad R, Dean C, Chen TL, Shannon-Dorcy K, Sandhu V, Hendrie PC, Scott BL, Walter RB, Becker PS, et al. 2015. Idarubicin, cytarabine, and pravastatin as induction therapy for untreated acute myeloid leukemia and high-risk myelodysplastic syndrome. Am J Hematol 90: 483-486. doi:10.1002/ajh.23981

Sharon D, Cathelin S, Mirali S, Di Trani JM, Yanofsky DJ, Keon KA, Rubinstein JL, Schimmer AD, Ketela T, Chan SM. 2019. Inhibition of mitochondrial translation overcomes venetoclax resistance in AML through activation of the integrated stress response. Sci Transl Med 11: eaax2863. doi:10.1126/scitranslmed.aax2863

Shim H, Dolde C, Lewis BC, Wu CS, Dang G, Jungmann RA, Dalla-Favera R, Dang CV. 1997. c-Myc transactivation of $L D H-A$ : Implications for tumor metabolism and growth. Proc Natl Acad Sci 94: 6658-6663. doi:10.1073/pnas.94 .13 .6658

Shojaee S, Chan LN, Buchner M, Cazzaniga V, Cosgun KN, Geng H, Qiu YH, von Minden MD, Ernst T, Hochhaus A, et al. 2016. PTEN opposes negative selection and enables oncogenic transformation of pre-B cells. Nat Med 22: 379-387. doi:10.1038/nm.4062

Singh K, Lin J, Zhong Y, Burčul A, Mohan P, Jiang M, Sun L, Yong-Gonzalez V, Viale A, Cross JR, et al. 2019. c-MYC regulates mRNA translation efficiency and start-site selection in lymphoma. J Exp Med. 216: 1509-1524.

Škrtić M, Sriskanthadevan S, Jhas B, Gebbia M, Wang X, Wang Z, Hurren R, Jitkova Y, Gronda M, Maclean N, et al. 2011. Inhibition of mitochondrial translation as a therapeutic strategy for human acute myeloid leukemia. Cancer Cell 20: 674-688. doi:10.1016/j.ccr.2011.10.015

Sommermann TG, O’Neill K, Plas DR, Cahir-McFarland E. 2011. IKK $\beta$ and NF- $\kappa B$ transcription govern lymphoma cell survival through AKT-induced plasma membrane trafficking of GLUT1. Cancer Res 71: 7291-7300. doi:10 1158/0008-5472.CAN-11-1715

Son J, Lyssiotis CA, Ying H, Wang X, Hua S, Ligorio M, Perera RM, Ferrone CR, Mullarky E, Shyh-Chang N, et al. 2013. Glutamine supports pancreatic cancer growth through a KRAS-regulated metabolic pathway. Nature 496: 101-105. doi:10.1038/nature12040

Southam AD, Khanim FL, Hayden RE, Constantinou JK, Koczula KM, Michell RH, Viant MR, Drayson MT, Bunce CM. 2015. Drug redeployment to kill leukemia and lymphoma cells by disrupting SCD1-mediated synthesis of monounsaturated fatty acids. Cancer Res 75: 2530-2540. doi:10.1158/0008-5472.CAN-15-0202

Sriskanthadevan S, Jeyaraju DV, Chung TE, Prabha S, Xu W, Skrtic M, Jhas B, Hurren R, Gronda M, Wang X, et al. 2015. AML cells have low spare reserve capacity in their respiratory chain that renders them susceptible to oxidative metabolic stress. Blood 125: 2120-2130. doi:10.1182/ blood-2014-08-594408

Stein EM, DiNardo CD, Pollyea DA, Fathi AT, Roboz GJ, Altman JK, Stone RM, DeAngelo DJ, Levine RL, Flinn IW, et al. 2017. Enasidenib in mutant $I D H 2$ relapsed or refractory acute myeloid leukemia. Blood 130: 722-731. doi:10.1182/blood-2017-04-779405

Stine ZE, Walton ZE, Altman BJ, Hsieh AL, Dang CV. 2015. MYC, metabolism, and cancer. Cancer Discov 5: 1024 1039. doi:10.1158/2159-8290.CD-15-0507

Stuart SD, Schauble A, Gupta S, Kennedy AD, Keppler BR, Bingham PM, Zachar Z. 2014. A strategically designed small molecule attacks $\alpha$-ketoglutarate dehydrogenase in tumor cells through a redox process. Cancer Metab 2: 4. doi:10.1186/2049-3002-2-4

Su R, Dong L, Li C, Nachtergaele S, Wunderlich M, Qing Y, Deng X, Wang Y, Weng X, Hu C, et al. 2018. R-2HG exhibits anti-tumor activity by targeting $\mathrm{FTO} / \mathrm{m}^{6} \mathrm{~A} /$ MYC/CEBPA signaling. Cell 172: 90-105.e23. doi:10 $.1016 /$ j.cell.2017.11.031

Sulkowski PL, Corso CD, Robinson ND, Scanlon SE, Purshouse KR, Bai H, Liu Y, Sundaram RK, Hegan DC, Fons NR, et al. 2017. 2-Hydroxyglutarate produced by neomorphic IDH mutations suppresses homologous recombination and induces PARP inhibitor sensitivity. Sci Transl Med 9: eaal2463. doi:10.1126/scitranslmed .aal2463

Sulkowski PL, Oeck S, Dow J, Economos NG, Mirfakhraie L, Liu Y, Noronha K, Bao X, Li J, Shuch BM, et al. 2020. Oncometabolites suppress DNA repair by disrupting local chromatin signalling. Nature 582: 586-591. doi:10 .1038/s41586-020-2363-0

Sullivan LB, Chandel NS. 2014. Mitochondrial reactive oxygen species and cancer. Cancer Metab 2: 17. doi:10.1186/ 2049-3002-2-17 
Sullivan LB, Gui DY, Hosios AM, Bush LN, Freinkman E, Vander Heiden MG. 2015. Supporting aspartate biosynthesis is an essential function of respiration in proliferating cells. Cell 162: 552-563. doi:10.1016/j.cell.2015.07 .017

Sullivan LB, Luengo A, Danai LV, Bush LN, Diehl FF, Hosios AM, Lau AN, Elmiligy S, Malstrom S, Lewis CA, et al. 2018. Aspartate is an endogenous metabolic limitation for tumour growth. Nat Cell Biol 20: 782-788. doi:10.1038/ s41556-018-0125-0

Sykes DB, Kfoury YS, Mercier FE, Wawer MJ, Law JM, Haynes MK, Lewis TA, Schajnovitz A, Jain E, Lee D, et al. 2016. Inhibition of dihydroorotate dehydrogenase overcomes differentiation blockade in acute myeloid leukemia. Cell 167: 171-186.e15. doi:10.1016/j.cell.2016.08 .057

Szlosarek PW. 2014. Arginine deprivation and autophagic cell death in cancer. Proc Natl Acad Sci 111: 14015-14016. doi:10.1073/pnas.1416560111

Tiziani S, Kang Y, Harjanto R, Axelrod J, Piermarocchi C, Roberts W, Paternostro G. 2013. Metabolomics of the tumor microenvironment in pediatric acute lymphoblastic leukemia. PLoS One 8: e82859. doi:10.1371/journal .pone.0082859

Trachootham D, Alexandre J, Huang P. 2009. Targeting cancer cells by ROS-mediated mechanisms: A radical therapeutic approach? Nat Rev Drug Discov 8: 579-591. doi:10 $.1038 / \mathrm{nrd} 2803$

Tsai HJ, Jiang SS, Hung WC, Borthakur G, Lin SF, Pemmaraju N, Jabbour E, Bomalaski JS, Chen YP, Hsiao HH, et al. 2017. A phase II study of arginine deiminase (ADIPEG20) in relapsed/refractory or poor-risk acute myeloid leukemia patients. Sci Rep 7: 11253. doi:10.1038/s41598017-10542-4

Turcan S, Rohle D, Goenka A, Walsh LA, Fang F, Yilmaz E, Campos C, Fabius AW, Lu C, Ward PS, et al. 2012. IDH1 mutation is sufficient to establish the glioma hypermethylator phenotype. Nature 483: 479-483. doi:10 $.1038 /$ nature10866

Tzoneva G, Perez-Garcia A, Carpenter Z, Khiabanian H, Tosello V, Allegretta M, Paietta E, Racevskis J, Rowe JM, Tallman MS, et al. 2013. Activating mutations in the NT5C2 nucleotidase gene drive chemotherapy resistance in relapsed ALL. Nat Med 19: 368-371. doi:10 .1038/nm.3078

Tzoneva G, Dieck CL, Oshima K, Ambesi-Impiombato A, Sánchez-Martín M, Madubata CJ, Khiabanian H, Yu J, Waanders E, Iacobucci I, et al. 2018. Clonal evolution mechanisms in NT5C2 mutant-relapsed acute lymphoblastic leukaemia. Nature 553: 511-514. doi:10.1038/na ture25186

Vander Heiden MG, DeBerardinis RJ. 2017. Understanding the intersections between metabolism and cancer biology. Cell 168: 657-669. doi:10.1016/j.cell.2016.12.039

Vander Heiden MG, Cantley LC, Thompson CB. 2009. Understanding the Warburg effect: The metabolic requirements of cell proliferation. Science 324: 1029-1033. doi:10 $.1126 /$ science. 1160809

Wang F, Travins J, DeLaBarre B, Penard-Lacronique V, Schalm S, Hansen E, Straley K, Kernytsky A, Liu W, Gliser C, et al. 2013. Targeted inhibition of mutant IDH2 in
Metabolic Hallmarks of Leukemia and Lymphoma

leukemia cells induces cellular differentiation. Science 340: 622-626. doi:10.1126/science.1234769

Wang YH, Israelsen WJ, Lee D, Yu VWC, Jeanson NT, Clish CB, Cantley LC, Vander Heiden MG, Scadden DT. 2014. Cell-state-specific metabolic dependency in hematopoiesis and leukemogenesis. Cell 158: 1309-1323. doi:10 .1016/j.cell.2014.07.048

Wang C, McKeithan TW, Gong Q, Zhang W, Bouska A, Rosenwald A, Gascoyne RD, Wu X, Wang J, Muhammad $\mathrm{Z}$, et al. 2015a. $I D H 2^{R 172}$ mutations define a unique subgroup of patients with angioimmunoblastic T-cell lymphoma. Blood 126: 1741-1752. doi:10.1182/blood-201505-644591

Wang ES, Frankfurt O, Orford KW, Bennett M, Flinn IW, Maris M, Konopleva M. 2015b. Phase 1 study of CB-839, a first-in-class, orally administered small molecule inhibitor of glutaminase in patients with relapsed/refractory leukemia. Blood 126: 2566. doi:10.1182/blood.V126.23 .2566 .2566

Wang P, Wu J, Ma S, Zhang L, Yao J, Hoadley KA, Wilkerson MD, Perou CM, Guan KL, Ye D, et al. 2015c. Oncometabolite D-2-hydroxyglutarate inhibits ALKBH DNA repair enzymes and sensitizes IDH mutant cells to alkylating agents. Cell Rep 13: 2353-2361. doi:10.1016/j.celrep 2015.11.029

Wang F, Gatica D, Ying ZX, Peterson LF, Kim P, Bernard D, Saiya-Cork K, Wang S, Kaminski MS, Chang AE, et al. 2019a. Follicular lymphoma-associated mutations in vacuolar ATPase ATP6V1B2 activate autophagic flux and mTOR. J Clin Invest 129: 1626-1640. doi:10.1172/ JCI98288

Wang LW, Shen H, Nobre L, Ersing I, Paulo JA, Trudeau S, Wang Z, Smith NA, Ma Y, Reinstadler B, et al. 2019b. Epstein-Barr-virus-induced one-carbon metabolism drives B cell transformation. Cell Metab 30: 539-555. e11. doi:10.1016/j.cmet.2019.06.003

Wang LW, Wang Z, Ersing I, Nobre L, Guo R, Jiang S, Trudeau S, Zhao B, Weekes MP, Gewurz BE. 2019c. EpsteinBarr virus subverts mevalonate and fatty acid pathways to promote infected B-cell proliferation and survival. PLoS Pathog 15: e1008030. doi:10.1371/journal.ppat.1008030

Warburg O. 1924. Uber den Stoffwechsel der Karzinomezellen. Biochem Z 152: 309-344.

Warburg O. 1956. On the origin of cancer cells. Science 123: 309-314. doi:10.1126/science.123.3191.309

Ward PS, Patel J, Wise DR, Abdel-Wahab O, Bennett BD, Coller HA, Cross JR, Fantin VR, Hedvat CV, Perl AE, et al. 2010. The common feature of leukemia-associated IDH1 and IDH2 mutations is a neomorphic enzyme activity converting $\alpha$-ketoglutarate to 2 -hydroxyglutarate. Cancer Cell 17: 225-234. doi:10.1016/j.ccr.2010.01.020

Weiser MA, Cabanillas ME, Konopleva M, Thomas DA, Pierce SA, Escalante CP, Kantarjian HM, O’Brien SM. 2004. Relation between the duration of remission and hyperglycemia during induction chemotherapy for acute lymphocytic leukemia with a hyperfractionated cyclophosphamide, vincristine, doxorubicin, and dexamethasone/methotrexate-cytarabine regimen. Cancer 100: 1179-1185. doi:10.1002/cncr.20071

Williams RT, Guarecuco R, Gates LA, Barrows D, Passarelli MC, Carey B, Baudrier L, Jeewajee S, La K, Prizer B, et al. 2020. ZBTB1 regulates asparagine synthesis and leukemia 
M. Stahl et al.

cell response to L-asparaginase. Cell Metab 31: 852-861. e6. doi:10.1016/j.cmet.2020.03.008

Wise DR, Thompson CB. 2010. Glutamine addiction: A new therapeutic target in cancer. Trends Biochem Sci 35: 427433. doi:10.1016/j.tibs.2010.05.003

Wong WW, Dimitroulakos J, Minden MD, Penn LZ. 2002. HMG-CoA reductase inhibitors and the malignant cell: The statin family of drugs as triggers of tumor-specific apoptosis. Leukemia 16: 508-519. doi:10.1038/sj.leu .2402476

Wu C, Gupta N, Huang YH, Zhang HF, Alshareef A, Chow A, Lai R. 2018a. Oxidative stress enhances tumorigenicity and stem-like features via the activation of the $\mathrm{Wnt} / \beta$ catenin/MYC/Sox2 axis in ALK-positive anaplastic large-cell lymphoma. BMC Cancer 18: 361. doi:10.1186/ s12885-018-4300-2

Wu D, Wang W, Chen W, Lian F, Lang L, Huang Y, Xu Y, Zhang N, Chen Y, Liu M, et al. 2018b. Pharmacological inhibition of dihydroorotate dehydrogenase induces apoptosis and differentiation in acute myeloid leukemia cells. Haematologica 103: 1472-1483. doi:10.3324/haema tol.2018.188185

Xia H, Wang W, Crespo J, Kryczek I, Li W, Wei S, Bian Z Maj T, He M, Liu RJ, et al. 2017. Suppression of FIP200 and autophagy by tumor-derived lactate promotes naive T cell apoptosis and affects tumor immunity. Sci Immunol 2: eaan 4631.

Xiao G, Chan LN, Klemm L, Braas D, Chen Z, Geng H, Zhang QC, Aghajanirefah A, Cosgun KN, Sadras T, et al. 2018. B-cell-specific diversion of glucose carbon utilization reveals a unique vulnerability in B cell malignancies. Cell 173: 470-484.e18. doi:10.1016/j.cell.2018.02.048

Xiong J, Wang L, Fei XC, Jiang XF, Zheng Z, Zhao Y, Wang CF, Li B, Chen SJ, Janin A, et al. 2017. MYC is a positive regulator of choline metabolism and impedes mitophagydependent necroptosis in diffuse large B-cell lymphoma. Blood Cancer J 7: e0.

Xu RH, Pelicano H, Zhang H, Giles FJ, Keating MJ, Huang P. 2005. Synergistic effect of targeting mTOR by rapamycin and depleting ATP by inhibition of glycolysis in lymphoma and leukemia cells. Leukemia 19: 2153-2158. doi:10 $.1038 /$ sj.leu.2403968

Ye J, Kumanova M, Hart LS, Sloane K, Zhang H, De Panis DN, Bobrovnikova-Marjon E, Diehl JA, Ron D, Koumenis C. 2010. The GCN2-ATF4 pathway is critical for tumour cell survival and proliferation in response to nutrient deprivation. $E M B O J$ 29: 2082-2096. doi:10 .1038/emboj.2010.81

Ye H, Adane B, Khan N, Sullivan T, Minhajuddin M, Gasparetto M, Stevens B, Pei S, Balys M, Ashton JM, et al. 2016. Leukemic stem cells evade chemotherapy by meta- bolic adaptation to an adipose tissue niche. Cell Stem Cell 19: 23-37. doi:10.1016/j.stem.2016.06.001

Ye D, Guan KL, Xiong Y. 2018a. Metabolism, activity, and targeting of D- and L-2-hydroxyglutarates. Trends Cancer 4: 151-165. doi:10.1016/j.trecan.2017.12.005

Ye H, Adane B, Khan N, Alexeev E, Nusbacher N, Minhajuddin $\mathrm{M}$, Stevens BM, Winters AC, Lin X, Ashton JM, et al. 2018b. Subversion of systemic glucose metabolism as a mechanism to support the growth of leukemia cells. Cancer Cell 34: 659-673.e6. doi:10.1016/j.ccell.2018.08.016

Yen K, Travins J, Wang F, David MD, Artin E, Straley K, Padyana A, Gross S, DeLaBarre B, Tobin E, et al. 2017. AG-221, a first-in-class therapy targeting acute myeloid leukemia harboring oncogenic $I D H 2$ mutations. Cancer Discov 7: 478-493. doi:10.1158/2159-8290.CD-16-1034

Ying H, Kimmelman AC, Lyssiotis CA, Hua S, Chu GC, Fletcher-Sananikone E, Locasale JW, Son J, Zhang H, Coloff JL, et al. 2012. Oncogenic Kras maintains pancreatic tumors through regulation of anabolic glucose metabolism. Cell 149: 656-670. doi:10.1016/j.cell.2012.01.058

Ying ZX, Jin M, Peterson LF, Bernard D, Saiya-Cork K, Yildiz M, Wang S, Kaminski MS, Chang AE, Klionsky DJ, et al. 2016. Recurrent mutations in the MTOR regulator RRAGC in follicular lymphoma. Clin Cancer Res 22: 5383-5393. doi:10.1158/1078-0432.CCR-16-0609

Yun J, Rago C, Cheong I, Pagliarini R, Angenendt P, Rajagopalan $\mathrm{H}$, Schmidt K, Willson JK, Markowitz S, Zhou $S$, et al. 2009. Glucose deprivation contributes to the development of KRAS pathway mutations in tumor cells. Science 325: 1555-1559. doi:10.1126/science.1174229

Yun J, Mullarky E, Lu C, Bosch KN, Kavalier A, Rivera K, Roper J, Chio II, Giannopoulou EG, Rago C, et al. 2015. Vitamin C selectively kills KRAS and BRAF mutant colorectal cancer cells by targeting GAPDH. Science 350: 1391-1396. doi:10.1126/science.aaa5004

Zhang W, Trachootham D, Liu J, Chen G, Pelicano H, Garcia-Prieto C, Lu W, Burger JA, Croce CM, Plunkett W, et al. 2012. Stromal control of cystine metabolism promotes cancer cell survival in chronic lymphocytic leukaemia. Nat Cell Biol 14: 276-286. doi:10.1038/ncb2432

Zhang L, Yao Y, Zhang S, Liu Y, Guo H, Ahmed M, Bell T, Zhang H, Han G, Lorence E, et al. 2019a. Metabolic reprogramming toward oxidative phosphorylation identifies a therapeutic target for mantle cell lymphoma. Sci Transl Med 11: eaau1167.

Zhang Y, Tan H, Daniels JD, Zandkarimi F, Liu H, Brown LM, Uchida K, O'Connor OA, Stockwell BR. 2019b. Imidazole ketone erastin induces ferroptosis and slows tumor growth in a mouse lymphoma model. Cell Chem Biol 26: 623-633.e9. 


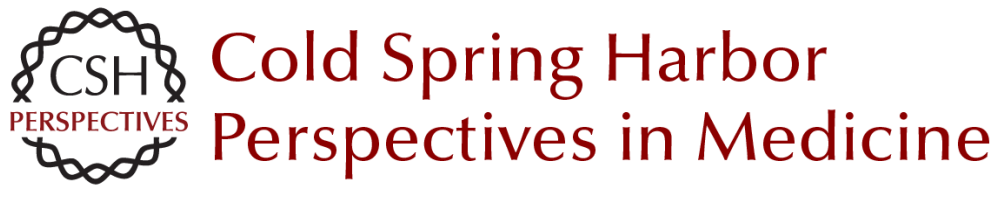

\title{
Oncogenic Mechanisms and Therapeutic Targeting of Metabolism in Leukemia and Lymphoma
}

\author{
Maximilian Stahl, Zachary D. Epstein-Peterson and Andrew M. Intlekofer
}

Cold Spring Harb Perspect Med 2021; doi: 10.1101/cshperspect.a035477 originally published online August 17, 2020

Subject Collection Leukemia and Lymphoma: Molecular and Therapeutic Insights

Oncogenic Mechanisms and Therapeutic

Targeting of Metabolism in Leukemia and Lymphoma

Maximilian Stahl, Zachary D. Epstein-Peterson and Andrew M. Intlekofer

Non-Hodgkin Lymphomas: Malignancies Arising from Mature B Cells Jennifer Shingleton, Jie Wang, Carolyn Baloh, et al.

MAP-Kinase-Driven Hematopoietic Neoplasms: A Decade of Progress in the Molecular Age Rikhia Chakraborty, Omar Abdel-Wahab and Benjamin H. Durham

Mouse Models in the Study of Mature B-Cell Malignancies Laura Pasqualucci and Ulf Klein

Mouse Models of Myeloid Malignancies Faisal Basheer and George Vassiliou

Epigenetic Mechanisms in Leukemias and Lymphomas

Cihangir Duy, Wendy Béguelin and Ari Melnick

The Biology of B-Progenitor Acute Lymphoblastic Leukemia

Kathryn G. Roberts and Charles G. Mullighan

RNA Regulators in Leukemia and Lymphoma Camila Prieto and Michael G. Kharas
Biological and Translational Considerations regarding the Recent Therapeutic Successes and Upcoming Challenges for Multiple Myeloma Constantine S. Mitsiades

Biology and Molecular Pathogenesis of Mature T-Cell Lymphomas José R. Cortés and Teresa Palomero

The Role of Somatic Mutations in Acute Myeloid Leukemia Pathogenesis Ashwin Kishtagari and Ross L. Levine

Chronic Lymphocytic Leukemia Nicholas Chiorazzi, Shih-Shih Chen and Kanti $R$. Rai

Normal Hematopoiesis Is a Balancing Act of Self-Renewal and Regeneration Oakley C. Olson, Yoon-A Kang and Emmanuelle Passegué

Impact of Genetics on Mature Lymphoid

Leukemias and Lymphomas Nathanael G. Bailey and Kojo S.J. Elenitoba-Johnson

Epidemiology and Etiology of Leukemia and Lymphoma Jordan A. Baeker Bispo, Paulo S. Pinheiro and Erin K. Kobetz

Clonal Hematopoiesis and Premalignant Diseases Justin Kaner, Pinkal Desai, Nuria Mencia-Trinchant, et al.

For additional articles in this collection, see http://perspectivesinmedicine.cshlp.org/cgi/collection/ 